\title{
AU-Rich Element RNA Binding Proteins: At the Crossroads of Post-Transcriptional Regulation and Genome Integrity
}

\author{
Ahmed Sidali ${ }^{1}$ (D), Varsha Teotia ${ }^{1}$, Nadeen Shaikh Solaiman ${ }^{1}$, Nahida Bashir ${ }^{1}$, Radhakrishnan Kanagaraj ${ }^{1,2,+}$, \\ John J. Murphy ${ }^{1, *(\mathbb{D})}$ and Kalpana Surendranath ${ }^{1, *(D)}$ \\ 1 Genome Engineering Laboratory, School of Life Sciences, University of Westminster, 115 New Cavendish \\ Street, London W1W 6UW, UK; w1523183@my.westminster.ac.uk (A.S.); \\ w1657795@my.westminster.ac.uk (V.T.); n.shaikhsolaiman@westminster.ac.uk (N.S.S.); \\ w1625969@my.westminster.ac.uk (N.B.); k.radhakrishnan@westminster.ac.uk (R.K.) \\ 2 School of Life Sciences, University of Bedfordshire, Park Square, Luton LU1 3JU, UK \\ * Correspondence: j.murphy@westminster.ac.uk (J.J.M.); k.surendranath1@westminster.ac.uk (K.S.) \\ † Correspondence may also be addressed to: k.radhakrishnan@westminster.ac.uk (R.K.).
}

check for updates

Citation: Sidali, A.; Teotia, V.; Solaiman, N.S.; Bashir, N.; Kanagaraj, R.; Murphy, J.J.; Surendranath, K. AU-Rich Element RNA Binding Proteins: At the Crossroads of Post-Transcriptional Regulation and Genome Integrity. Int. J. Mol. Sci. 2022, 23, 96. https://doi.org/ $10.3390 /$ ijms 23010096

Academic Editor: Takahiko Shimizu

Received: 26 November 2021

Accepted: 18 December 2021

Published: 22 December 2021

Publisher's Note: MDPI stays neutral with regard to jurisdictional claims in published maps and institutional affiliations.

Copyright: (C) 2021 by the authors. Licensee MDPI, Basel, Switzerland. This article is an open access article distributed under the terms and conditions of the Creative Commons Attribution (CC BY) license (https:// creativecommons.org/licenses/by/ $4.0 /)$.

\begin{abstract}
Genome integrity must be tightly preserved to ensure cellular survival and to deter the genesis of disease. Endogenous and exogenous stressors that impose threats to genomic stability through DNA damage are counteracted by a tightly regulated DNA damage response (DDR). RNA binding proteins (RBPs) are emerging as regulators and mediators of diverse biological processes. Specifically, RBPs that bind to adenine uridine (AU)-rich elements (AREs) in the $3^{\prime}$ untranslated region (UTR) of mRNAs (AU-RBPs) have emerged as key players in regulating the DDR and preserving genome integrity. Here we review eight established AU-RBPs (AUF1, HuR, KHSRP, TIA-1, TIAR, ZFP36, ZFP36L1, ZFP36L2) and their ability to maintain genome integrity through various interactions. We have reviewed canonical roles of AU-RBPs in regulating the fate of mRNA transcripts encoding DDR genes at multiple post-transcriptional levels. We have also attempted to shed light on non-canonical roles of AU-RBPs exploring their post-translational modifications (PTMs) and sub-cellular localization in response to genotoxic stresses by various factors involved in DDR and genome maintenance. Dysfunctional AU-RBPs have been increasingly found to be associated with many human cancers. Further understanding of the roles of AU-RBP in maintaining genomic integrity may uncover novel therapeutic strategies for cancer.
\end{abstract}

Keywords: Adenine-Uridine rich element; RNA binding proteins; replication stress; genome stability; DNA damage response; post-transcriptional regulation; oncogenes; tumour suppressors; cancer

\section{Introduction}

Living cells are constantly engaged in a battle to alleviate and prevent DNA lesions that compromise genome integrity. It is estimated that each nucleated cell in the human body experiences more than 100,000 lesions per day [1]. Approximately $75 \%$ of these lesions are due to endogenous sources and occur following oxidative damage, base hydrolysis or as intermediates in DNA repair [1,2]. Furthermore, more deleterious lesions such as DNA double-strand breaks (DSBs) that occur less frequently arise as a consequence of exposure to both endogenous and exogenous sources of DNA damage. In particular, some DSBs can form when two single-strand DNA breaks (SSBs) are in close proximity or, following an encounter between the DNA replication machinery components with DNA lesions [3]. Many of these DNA lesions can be attributed to products of cellular metabolism, such as reactive metabolites, free radicals, and exposure to exogenous insults such as ultraviolet light (UV), ionising radiation (IR) and DNA damaging agents (as reviewed in [3]). Unrepaired lesions threaten the integrity of the genome and have been shown to serve as enablers of disease pathogenesis including cancers, neurodegenerative disorders and immunodeficiencies [4-7]. To maintain essential cellular functions and 
faithful transmission of genetic material to the next generation, cells harbour DNA damage response (DDR) mechanisms that continuously monitor and signal the presence of DNA damage at cell cycle checkpoints, activating pathways to initiate repair (Figures 1 and 2). The key sensors of the DDR consist of proteins that identify DNA lesions resulting in the activation of DDR kinases upstream of a signaling cascade. Essential to the signaling cascade are mediator proteins that facilitate the phosphorylation of key factors that regulate transcription and the DDR network [8]. Effectors of the DDR are downstream substrates involved in a plethora of cellular activities, such as DNA replication, repair, and cell-cycle regulation; all of these activities are crucial for the maintenance of genome integrity [8].

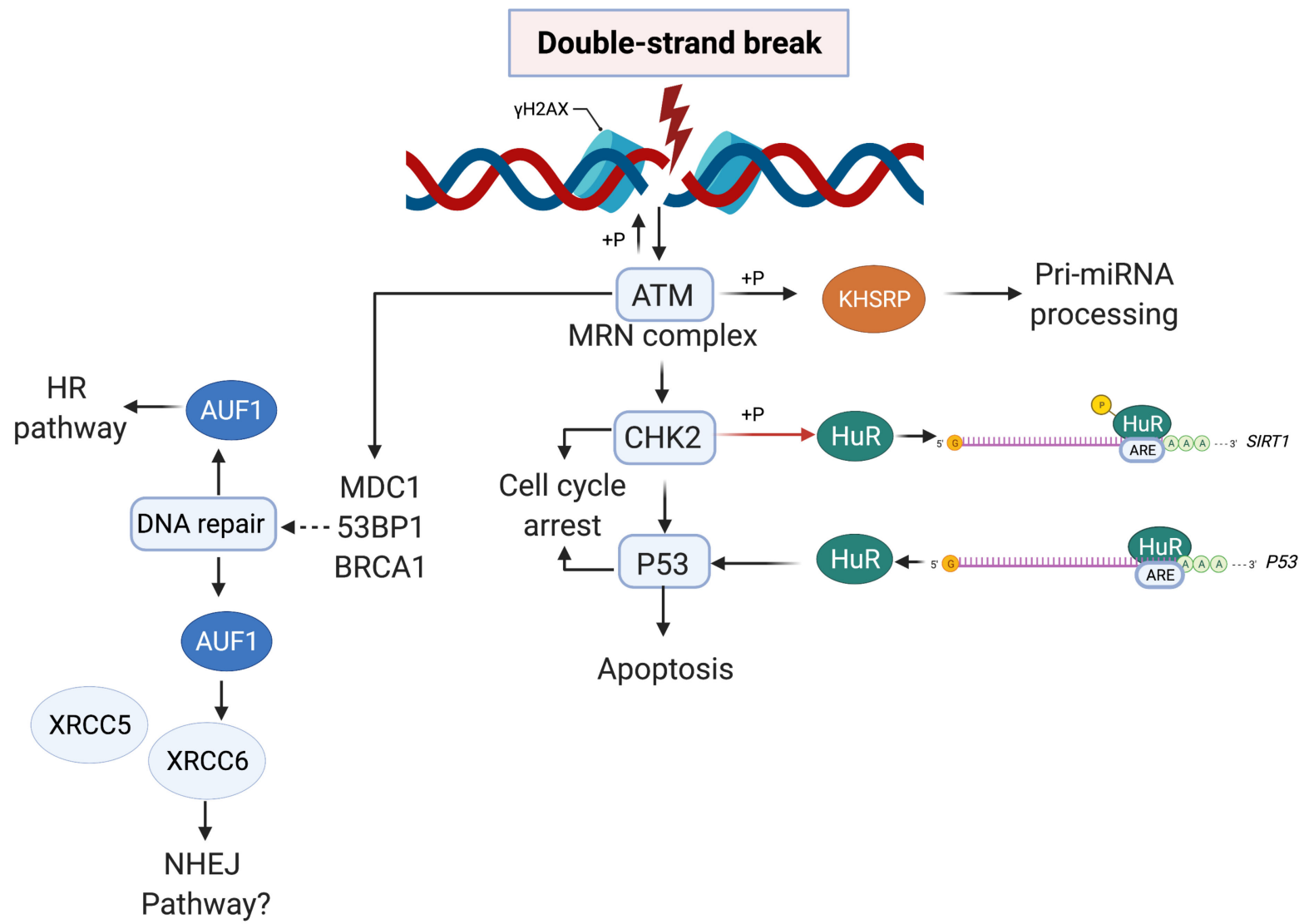

Figure 1. AU-RBPs at the nexus of the double strand break repair. DSBs initiated by endogenous or exogenous sources (red bolt) primarily lead to the activation of ATM. Initially, exposed DNA ends are sensed by the Mre11-Rad50-Nbs1 (MRN) complex, a key regulator of ATM activation, resulting in phosphorylation $(+\mathrm{P})$ and activation of ATM. Activated ATM, phosphorylates downstream effectors CHK2, p53, BRCA1, and 53BP1 mediating cell-cycle arrest, apoptosis, and DNA repair through homologous recombination (HR) or non-homologous end-joining (NHEJ) pathways. ATM-directed phosphorylation of histone 2AX at serine $139(\gamma \mathrm{H} 2 \mathrm{AX})$ is recognised by MDC1, resulting in widespread activation of $\gamma \mathrm{H} 2 \mathrm{AX}$ over chromatin domains recruiting DNA repair factors at the site of DNA damage. AU-RBPs have been reported to form direct interactions, such as, KHSRPs phosphorylation by ATM early in the DSB pathway promoting KHSRP's role in pri-miRNA processing. AU-RBP HuR is phosphorylated by $\mathrm{CHK} 2$ promoting destabilsation of target mRNA sirt1. Alternatively, HuR may also stabilise p53 mRNA, promoting p53 translation to coordinate the DDR. AU-RBP AUF1 has been shown to associate with DSB repair through HR and may also interact with proteins involved in NHEJ, such as XRCC5 and XRCC6 (discussed below). 


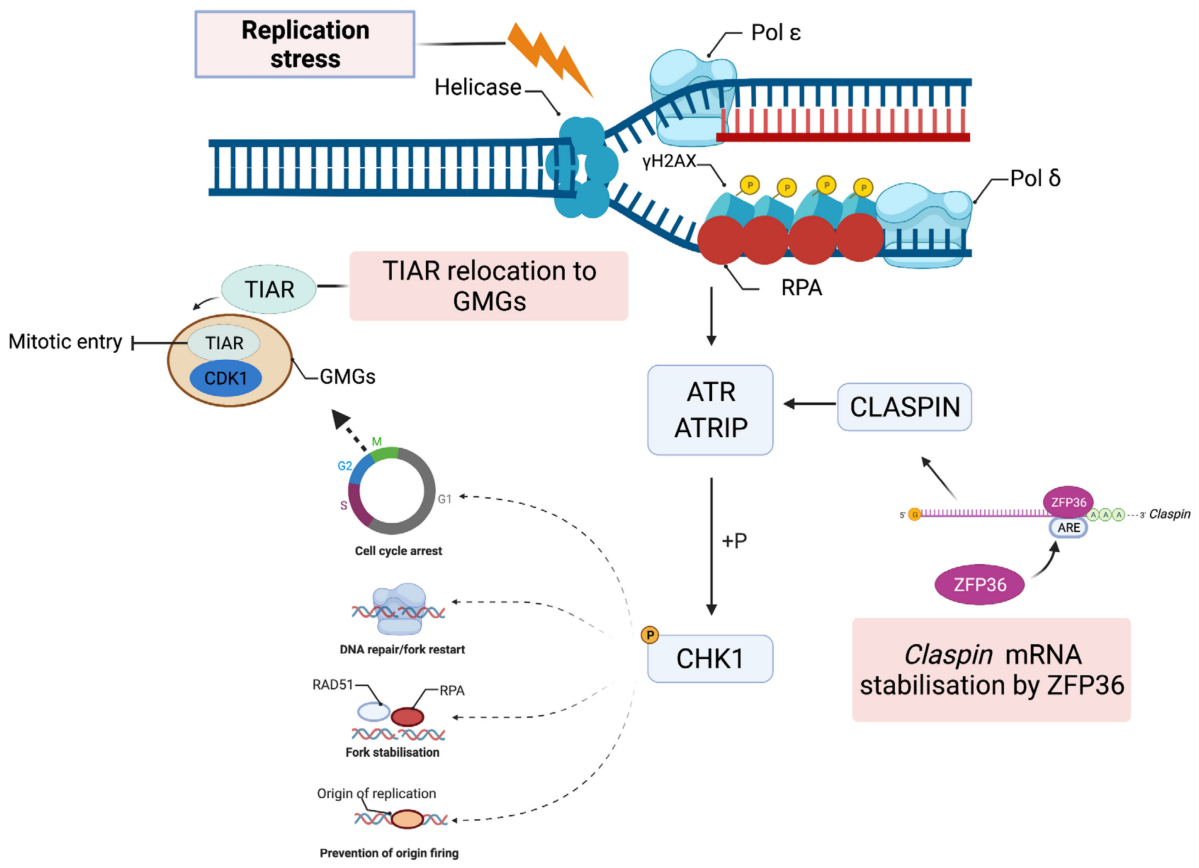

Figure 2. AU-RBPs at the nexus of the replication stress response. The eukaryotic replicative helicase complex unwinds parental DNA enabling replication of the leading and lagging strands by DNA polymerase Pol $\varepsilon$ and Pol $\delta$ respectively. Replication stress can result in stalled replication fork progression (orange bolt) leading to stretches of single-stranded DNA (ssDNA) as the DNA continues to unwind. ssDNA becomes bound and protected by the ssDNA binding protein replication protein A (RPA), initiating ATR kinase recruitment. ATR recruitment is facilitated by interactions with ATR interacting protein (ATRIP), resulting in downstream activation of factors involved in the resolution of compromised replication forks. For ATR to phosphorylate its primary target, the master regulator CHK1 and CLASPIN must bind to RPA enabling phosphorylation of CHK1 at serine residues 317 and 345. This is accompanied by the phosphorylation of H2A histone family member $\mathrm{x}(\mathrm{H} 2 \mathrm{AX})$ at serine $139(\gamma \mathrm{H} 2 \mathrm{AX})$ early in the replication stress response. Activation of CHK1 ensures faithful restoration of the replication fork by initiating cell-cycle arrest, preventing origin firing, promoting fork stabilisation, DNA repair, and fork restart. The AU-RBP ZFP36 has been reported to be a key component in mediating faithful activation of CHK1 by ATR, by increasing the stability of CLASPIN mRNA. AU-RBP TIAR has been linked to arresting cell cycle at the G2/M border in response to replication stress by attenuating CDK1 in G2/M transition granules (GMGs) inhibiting entry into mitosis (discussed below).

\section{The Eukaryotic DNA Damage Network}

At the heart of DDR are three serine/threonine kinases of the phosphatidylinositol3-kinase-like kinase family (PIKKs): ATM (ataxia-telangiectasia mutated), ATR (ATM and Rad3-related), and DNA-PK (DNA-dependent protein kinase) [9]. ATR and ATM are the master transducers of signaling through the DNA damage pathway and these kinases mediate the phosphorylation of their primary downstream effectors; checkpoint kinase 1 (CHK1) and checkpoint kinase 2 (CHK2) [10]. The number of DNA-PK targets is considerably less than those of ATM or ATR, with DNA-PK primarily involved in DSB repair [9]. Multiple studies have demonstrated that the distinct characteristics of ATR and ATM are partially attributed to the nature of DNA damage [11-13]. ATM is activated in response to DNA double-strand breaks (DSBs) that are detected by meiotic recombination 11 homolog 1 (MRE11), ATP-binding cassette-ATPase (RAD50), and phosphopeptidebinding Nijmegen breakage syndrome protein 1 (NBS1) forming the MRE11-RAD50-NBS1 (MRN) complex. Formation of this complex leads to the recruitment and activation of downstream effectors associated with the ATM pathway (Figure 1) [11,14]. ATR becomes 
active in response to the formation of single stranded DNA (ssDNA) commonly induced by DNA replication stress, resected DSBs and junctions between ssDNA and double-stranded DNA that are coated in heterotrimeric replication protein A (RPA) (Figure 2) [9,15]. Once activated, ATM and ATR result in the downstream activation of CHK1 and CHK2 that inhibit cyclin-dependent kinase (CDK) activity through multiple mechanisms [16,17]. CDK inhibition is required to slow down or inhibit cell cycle progression at specific cell cycle checkpoints: G1-S, intra-S, and G2-M [18]. Furthermore, signaling by ATM and ATR in the event of DNA damage upregulates the expression of DNA repair genes and mediates the recruitment of DDR proteins to sites of DNA damage through specific post-translational modifications such as phosphorylation, sumoylation, or acetylation [19]. The functional significance of many ATR/ATM-mediated phosphorylation events associated with DDR remains to be characterized [18,20]. Additionally, the expression of genes associated with DDR must also be tightly regulated to mediate an effective DDR as well as DNA repair. Extensive studies of the molecular networks of the DDR have also led to insights into dysregulation of these processes associated with cancer (as reviewed in [21]).

\section{Multifunctional AU-RBPs Maintain Genome Integrity}

In response to DNA damage, DDR orchestrates several processes, such as transcription inhibition, repression of $3^{\prime}$-end processing of mRNAs [22,23], reduction in the stability of mRNAs [24] and inhibition of translation factors [25] that are associated with initiation and elongation [26]. DNA damage is therefore associated with repression of gene expression that can be partially attributed to reduction in messenger RNA (mRNA) levels [27]. Additionally, global reduction in cell protein levels are also observed in the event of DNA damage, favouring translation of a subset of genes required during DDR [28]. For example, Microarray analysis performed on polysome-bound mRNAs demonstrated that, in response to DNA damage, DDR protein encoding mRNAs, selectively evade translational repression [28-30]. Pivotal to maintaining the expression of DDR genes upon DNA damage are RNA binding proteins (RBPs). RBPs modulate gene expression through the formation of ribonucleoprotein (RNP) complexes. This is achieved by their interactions with RNAs through sequence or structure specificities that are commonly located within mRNA untranslated regions (UTRs) and open reading frames (ORF) [31,32], as well as in pre-mRNAs in the nucleus.

This review focuses on presenting emerging evidence of multi-faceted roles for eight selected adenine-uridine (AU)rich element (ARE) RNA binding proteins (AU-RBPs) (Table 1) in maintaining genome integrity. Up to $8 \%$ of mRNA transcripts contain cis-acting ARE regulatory elements located within the $3^{\prime}$ UTR [33]. AU-RBPs are historically categorised as functioning in mRNA post-transcriptional regulation by virtue of their ability to bind to AU-rich regions in the $3^{\prime} \mathrm{UTR}$ of $\mathrm{mRNAs}$ and mediate either mRNA degradation or stabilisation (reviewed in [34]). They contain a diverse repertoire of biochemically and structurally characterised RNA-binding domains (RBD) that vary in structural arrangement. AU-RBPs utilise their RBD(s) to achieve ARE binding utilising canonical RBDs, such as the RNA recognition motifs (RRM), hnRNP K-homology (KH type I and type II) domains and $\mathrm{CCCH}$ zinc finger motifs [35]. Certain RBPs are not only limited to interacting with mRNA but have also been reported to interact with DNA. For example, KH type I and type II RBDs of AU-RBP KHSRP also exhibit binding to ssDNA (reviewed in [36]) and the RRM of AUF1 has been reported to also interact with the single-stranded human DNA telomeric repeat sequence d(TTAGGG)n [37]. Furthermore, AU-RBPs may contain one or several RBDs indicating their versatility to interact with multiple targets associated with various biological events [38-40]. AU-RBPs therefore maintain key roles in RNA metabolism regulating RNA maturation, stabilisation, degradation, surveillance and translation [41].

Dysfunctional AU-RBPs are linked to multiple diseases such as, neurodegenerative disorders, cardiovascular disease and cancer [42-44]. In addition to presenting evidence for the involvement of AU-RBPs in human diseases, we also explore reported involvement of these proteins in the maintenance of genome integrity [45-48]. 
Table 1. Multi-faceted roles of AU-rich RNA binding proteins in maintaining genome integrity.

\begin{tabular}{|c|c|c|c|}
\hline $\begin{array}{l}\text { Name } \\
\text { (Aliases) } \\
\text { AU-RBPs }\end{array}$ & $\begin{array}{l}\text { Chromosome } \\
\text { Location }\end{array}$ & Cell Replication Stress/DNA Damage Role & Role in Cancer-Selected Publications \\
\hline $\begin{array}{l}\text { AUF1 } \\
(\text { HNRNBP, } \\
\text { HNRPD) }\end{array}$ & $4 q 21.22$ & $\begin{array}{l}\text { Depletion of HNRNPD impairs homologous } \\
\text { recombination by inhibiting DNA-end } \\
\text { resection and inducing R-loop accumulation [48] }\end{array}$ & $\begin{array}{c}\text { AUF1 is overexpressed in esophageal } \\
\text { squamous cell carcinoma (ESCC) patient } \\
\text { tissue samples [49] } \\
\text { AUF1 overexpression promotes colorectal } \\
\text { cancer (CRC) progression [50] }\end{array}$ \\
\hline $\begin{array}{c}H u R \\
(E L A V L 1)\end{array}$ & 19 p13.2 & $\begin{array}{c}\text { HuR reduces radiation-induced DNA Damage by } \\
\text { enhancing the expression of ARID1A [51] } \\
\text { poly(A)+ RDH mRNAs are post-transcriptionally } \\
\text { regulated by HuR in cell stress conditions [52] } \\
\text { Component of R loop interactome [53] } \\
\text { HuR facilitates cellular senescence through } \\
\text { posttranscriptional regulation of TIN2 mRNA [54] } \\
\text { HuR stabilizes TFAM mRNA in an } \\
\text { ATM/p38-dependent } \\
\text { manner in irradiated cells [55] } \\
\text { PARG mRNA post-transcriptional regulation by } \\
\text { HuR facilitates DNA Repair [56] } \\
\text { Chk2 phosphorylates HuR following ionising } \\
\text { radiation [57] } \\
\text { Double-stranded breaks induce CHK2-mediated } \\
\text { phosphorylation of HuR in B lymphocytes [58] } \\
\text { HuR functions in oxidative stress pathways [59] } \\
\text { HuR post-transcriptionally regulates BRCA1 [60] } \\
\text { HuR enhances p53 translation in response to } \\
\text { ultraviolet light irradiation [61] } \\
\text { HuR regulates p21 mRNA stabilisation by UV } \\
\text { light [62] } \\
\text { HuR regulates cyclin A and cyclin B1 mRNA } \\
\text { stability during cell proliferation [63] }\end{array}$ & $\begin{array}{l}\text { HuR is elevated in clinical ductal invasive } \\
\text { carcinoma (DIC) and ductal carcinoma in } \\
\text { situ (DCIS) breast cancer samples [64,65] } \\
\text { Elevated HuR cytoplasmic expression is a } \\
\text { possible indicator of poor prognosis in } \\
\text { breast cancer patients that received } \\
\text { paclitaxel- and anthracycline-based } \\
\text { neoadjuvant chemotherapy (NACT) [66] } \\
\text { HuR is an oncogenic driver for malignant } \\
\text { peripheral nerve sheath tumours } \\
\text { (MPNSTs) [67] }\end{array}$ \\
\hline $\begin{array}{l}\text { KHSRP } \\
(K S R P)\end{array}$ & $19 \mathrm{p} 13.3$ & $\begin{array}{l}\text { DNA damage response phosphorylates KHSRP } \\
\text { leading to direct binding to pre-miRNAs promoting } \\
\text { miRNA biogenesis }[68,69]\end{array}$ & $\begin{array}{l}\text { KHSRP critical for the growth of melanoma } \\
\text { cells [70] } \\
\text { KHSRP upregulated in lung cancers [71,72] } \\
\text { KHSRP upregulated in colorectal cancer [73] }\end{array}$ \\
\hline $\begin{array}{l}\text { TIA1 (TIA-1) } \\
\text { TIAR (TIAL1) }\end{array}$ & $\begin{array}{c}2 \mathrm{p} 13.3 \\
10 \mathrm{q} 26.11\end{array}$ & $\begin{array}{l}\text { TIAR restricts G2/M transition under conditions of } \\
\text { replication stress [74] }\end{array}$ & $\begin{array}{c}\text { TIA1 and TIAR function as tumour } \\
\text { suppressors and low expression correlates } \\
\text { with poor prognosis in patients with lung } \\
\text { squamous cell carcinoma [75] }\end{array}$ \\
\hline $\begin{array}{l}\text { ZFP36 (TTP, } \\
\text { TIS11) }\end{array}$ & $19 \mathrm{q} 13.2$ & $\begin{array}{l}\text { Modulation of ATR-CHK1 activation upon DNA } \\
\text { damage through stabilisation of claspin mRNA [76] }\end{array}$ & $\begin{array}{l}\text { ZFP36 is suppressed in many cancers [77] } \\
\text { ZFP36 underexpressed in cancers of the } \\
\text { breast, lung and liver [78-80] }\end{array}$ \\
\hline $\begin{array}{l}\text { ZFP36L1 } \\
(T I S 11 b)\end{array}$ & $14 \mathrm{q} 24.1$ & $\begin{array}{c}\text { Early developing T cells in zfp36pl1 zfp36l2 double } \\
\text { knockout showed increased levels of DNA } \\
\text { double-stranded breaks marker } \gamma \mathrm{H} 2 \mathrm{AX}[81]\end{array}$ & $\begin{array}{c}\text { Deletion of zfp36pl1 and zfp36l2 in mice } \\
\text { leads to T lymphoblastic leukaemia [82] } \\
\text { ZFP36L1 identified as a breast cancer driver } \\
\text { gene [83] } \\
\text { ZFP36L1 identified as a multiple myeloma } \\
\text { driver gene [84] } \\
\text { CRISPR-KO of ZFP36L1 reduces cell growth } \\
\text { in chronic myeloid leukaemia cells [85] }\end{array}$ \\
\hline $\begin{array}{l}\text { ZFP36L2 } \\
(\text { TIS11d) }\end{array}$ & $2 \mathrm{p} 21$ & $\begin{array}{l}\text { ZFP36L2 is essential for cisplatin-induced DNA } \\
\text { damage-induced S-phase arrest [86] } \\
\text { Early developing T cells in } z f p 36 p l 1 \text { zfp36l2 double } \\
\text { knockout showed increased levels of DNA } \\
\text { double-stranded breaks marker } \gamma \mathrm{H} 2 \mathrm{AX} \text { [81] }\end{array}$ & $\begin{array}{l}\text { ZFP36L2 is overexpressed in gastric } \\
\text { cancer [87] } \\
\text { ZFP36L2 is overexpressed pancreatic } \\
\text { cancer [88] } \\
\text { ZFP36L2 is a prevalent driver gene in } \\
\quad \text { metastatic solid tumours [89] }\end{array}$ \\
\hline
\end{tabular}




\section{Post-Transcriptional Regulation of DDR Genes by AU-RBPs}

Numerous studies have reported that, in the event of DNA damage, AU-RBPs are able to modulate the expression of selected DDR genes. For example, $\mathrm{Hu}$ antigen $\mathrm{R}(\mathrm{HuR})$ binds to, stabilises and subsequently increases translation of a plethora of mRNA targets essential for cell cycle control and DNA repair such as; Cyclins (D1, E1, A2, B1), p53, and BRCA1 $[60,90]$. Furthermore, alterations to HuR activity in response to DNA damage have also been reported to modulate the expression of genes involved in the DDR [91]. $\mathrm{HuR}$ was reported to bind and stabilise $p 53 \mathrm{mRNA}$ in a manner dependent on exposure to short-wavelength UV light (UVC) in human colorectal carcinoma cells (Figure 1) [61]. Overexpression of HuR was shown to increase the abundance of p53, whereas HuR depletion diminished p53 translation [61]. Recently, HuR has been reported to reduce radiationinduced DNA damage through post-transcriptional regulation of NHEJ factor AT-rich interactive domain 1A (SWI-like) (ARID1A) a factor that promotes NHEJ, by increasing expression of ARID1A in response to ionising radiation [51,92]. Other AU-RBPs have also been shown to be important regulators of p53. In response to DNA damage-induced during B cell development, AU-RBP TIA1 dissociates and relocates p53 mRNA from stress granules to polysomes, allowing its rapid translation, required for generating a functional $\mathrm{B}$ cell-receptor [93]. Using TIA-in-vivo UV crosslinking and immunoprecipitation (TIA-iCLIP) we identified a subset of known p53-targeted genes that contains multiple binding sites and motifs available for TIA1 interaction in their $3^{\prime} \mathrm{UTR}$ region of mRNA transcripts [75]. Interestingly, TIA1 protein is found to be immunoprecipitated with various p53-targeted cell-cycle regulator mRNAs, including NUP98, GADD45B and CDKN1A, validating TIA1 function in modulating post-transcriptional levels of these DNA-Damage related mRNAs [94]. Thus, TIA1 dissociates and relocates multiple target mRNAs following DNA damage elicited by UV.

TIAR has been recently reported to act as a novel component of the replication stress response and to be an important regulator of the $\mathrm{G} 2 / \mathrm{M}$ transition required for arresting cells at the G2/M border (Figure 2) [74]. TIAR relocalises in stress induced nuclear foci, known as $\mathrm{G} 2 / \mathrm{M}$ transition granules (GMGs) at stalled replication forks that contain components of the transcription, splicing, DNA replication, and repair machinery [74]. Furthermore, TIAR attenuates CDK1 activity by retaining CDK1 within the GMGs during replication stress, a mechanism that requires TIAR's RNA binding capabilities [74]. During B cell activation, TIA1 sequesters p53 mRNA within stress granules in the cytoplasm, conferring translational repression of p53 mRNA [93].

AU-RBPs AUF1 and TIAR were reported to interact with the $3^{\prime}$ UTR of Gadd $45 \alpha$ (a transcript that is upregulated in response to stress stimuli) mRNA in response to genotoxic doses of methyl methanesulfonate (MMS). In unperturbed Hela cells, AUF1 was found to bind Gadd $45 \alpha$ mRNA, reducing its stability, whereas TIAR inhibited Gadd $45 \alpha$ translation. This association effect was shown to diminish following treatments with MMS, resulting in the dissociation of AUF1 and TIAR from Gadd $45 \alpha$ mRNA thereby increasing its half-life and translation [95].

Recently ZFP36, a member of the TTP family of proteins, was shown to modulate ATR-CHK1 activation following DNA damage through stabilisation of Claspin mRNA, a mediator of ATR-CHK1 interactions (Figure 2). ZFP36-dependent Claspin mRNA stabilisation facilitated ATR-CHK1-dependent replication fork stability to maintain chromosomal stability. Furthermore, depletion of ZFP36 compromised subsequent ATR-CHK1 activation and negatively impacted genome integrity [76]. Indirect evidence for the role of the ZFP36 family proteins, ZFP36L1 and ZFP36L2, in the DDR has also come from studies on developing lymphocytes in mice [81,96]. Concomitant deletion of zfp36pl1 and zfp36l2 in early developing T cells in the thymus increased levels of $\gamma \mathrm{H} 2 \mathrm{AX}$, a marker of DNA double-stranded breaks, and also increased phosphorylation of substrates of ATM/ATR kinases [81,96]. CRISPR-Cas9 knockout of ZFP36L1 in U2OS osteosarcoma cell line models increased markers of replication stress, including mitotic chromosome breaks, chromosome missegregation, incidence of micronuclei and 53BP1 G1-nuclear bodies [97]. Thus, it is pos- 
sible that zfp3611 and zfp3612 post-transcriptionally coordinate the expression of proteins involved in the DDR [96]. In support of this proposal [81,96], in vitro studies on human cell lines [98] have reported that ZFP36L1 and ZFP36L2 [98] can act as negative regulators of cell cycle progression by targeting numerous cell cycle associated mRNAs that have significant overlap with DDR genes, such as several Cyclins and CDKs [96].

In addition to the presence of AREs in the $3^{\prime}$ UTR of mRNAs, recent studies using transcriptome analysis techniques and computational biology approaches have revealed the existence of intronic AREs sequences present on pre-mRNAs in the cell nucleus [52,99-103]. To date, understanding the roles of intronic AREs in classic functions of AU-RBPs stabilising or destabilising RNA transcripts or effects on mRNA translation are in their infancy. There is, however, good evidence that HuR can function in RNA stabilisation of pre-mRNAs by virtue of intronic ARE binding [99,101,103]. For example, HuR knockdown in HEK293 cells resulted in reduced levels of mRNA for genes containing intronic AREs [103]. Along with AREs present in the 3'UTR of mRNAs, the discovery of intronic AREs has revealed that greater than $50 \%$ of human genes may contain AREs [103]. The relevance of roles of intronic AREs for AU-RBP functions in maintaining genomic integrity is currently unknown. However, AU-RBPs (Table 1) are all nucleo-cytoplasmic shuttling proteins; therefore, some potential nuclear roles for AU-RBPs in maintaining genomic integrity could involve intronic AREs.

\section{DNA Damage Induces Post-Translational Modifications of AU-RBPs}

Post-translational modifications (PTMs) play an important role in mediating and sustaining DDR signalling [18]. Phosphoproteomic screens have demonstrated that DNA damage regulates the phosphorylation of several RBPs $[20,104]$. Furthermore, these phosphorylation events can be attributed to DDR proteins, such as DNA damage sensors (ATM, ATR, and DNA-PK), transducers (CHK1 and CHK2), and multiple downstream kinases. AU-RBPs listed (Table 1) are targeted for PTMs by DDR proteins in the event of DNA damage. CHK2 has been previously shown to regulate $\mathrm{HuR}^{\prime} \mathrm{s}$ interaction with target mRNA in response to genotoxic doses of hydrogen peroxide $\left(\mathrm{H}_{2} \mathrm{O}_{2}\right)$ [105]. In human diploid fibroblasts, CHK2 phosphorylation of HuR was demonstrated to be an essential event in inducing its dissociation from the mRNA encoding the pro-cell survival factor Sirtuin 1(SIRT1), resulting in decreased SIRT1 expression (Figure 3) [105]. This process was shown to be largely mediated following phosphorylation of three HuR residues S88, S100 and T118 by CHK2 [105]. Specifically, S100 phosphorylation by CHK2 was shown to be essential for its dissociation from SIRT1 $m R N A$. In response to ionising radiation-induced DNA damage in B lymphocytes, HuR phosphorylation by CHK2 induced its association with mRNAs and thereby post-transcriptionally upregulated a number of proteins including ZFP36L1 [58]. HuR phosphorylation by CHK2 was further supported through microarray analysis in CHK2 proficient and deficient HCT116 colorectal carcinoma cells [57]. HuR was revealed to dissociate with target mRNAs in CHK2 proficient cells when exposed to ionising radiation, whereas HuR remained bound to mRNA targets in CHK2 - / - HCT116 cells [57]. Furthermore, mutations to HuR that inhibit its phosphorylation by CHK2 disrupted its dissociation from its mRNA targets following IR, reducing cell survival [57]. p38-mediated phosphorylation of the AU-RBP TIAR and concomitant MK2 (mitogen-activated protein kinase (MAPK)-activated protein kinase-2) mediated phosphorylation of hnRNP A0 and PARN was proposed to be involved in the regulation of Gadd $45 \alpha$ levels in response to genotoxic stress [106]. TIAR's dissociation from Gadd $45 \alpha$ mRNA via p38 phosphorylation was demonstrated to be an important initiating factor in Gadd $45 \alpha^{\prime}$ s subsequent stabilisation and expression following genotoxic stress (Figure 3). Gadd $45 \alpha$ blocks cell mitosis in the presence of unrepaired DNA. Specifically, RNA-IP of TIAR in doxorubicin-treated Hela cells demonstrated that TIAR's binding to Gadd $45 \alpha$ mRNA is directly correlated to p38 activity. In Hela cells with unperturbed p38, TIAR was able to dissociate from Gadd $45 \alpha$, whereas p38 inhibition restored TIAR's binding to Gadd45 $\alpha$. Furthermore, in vitro kinase assays revealed strong phosphorylation of TIAR by p38 following genotoxic stress, imply- 
ing that TIAR's dissociation from Gadd45 $\alpha$ is achieved following p38 mediated PTM of TIAR [106].

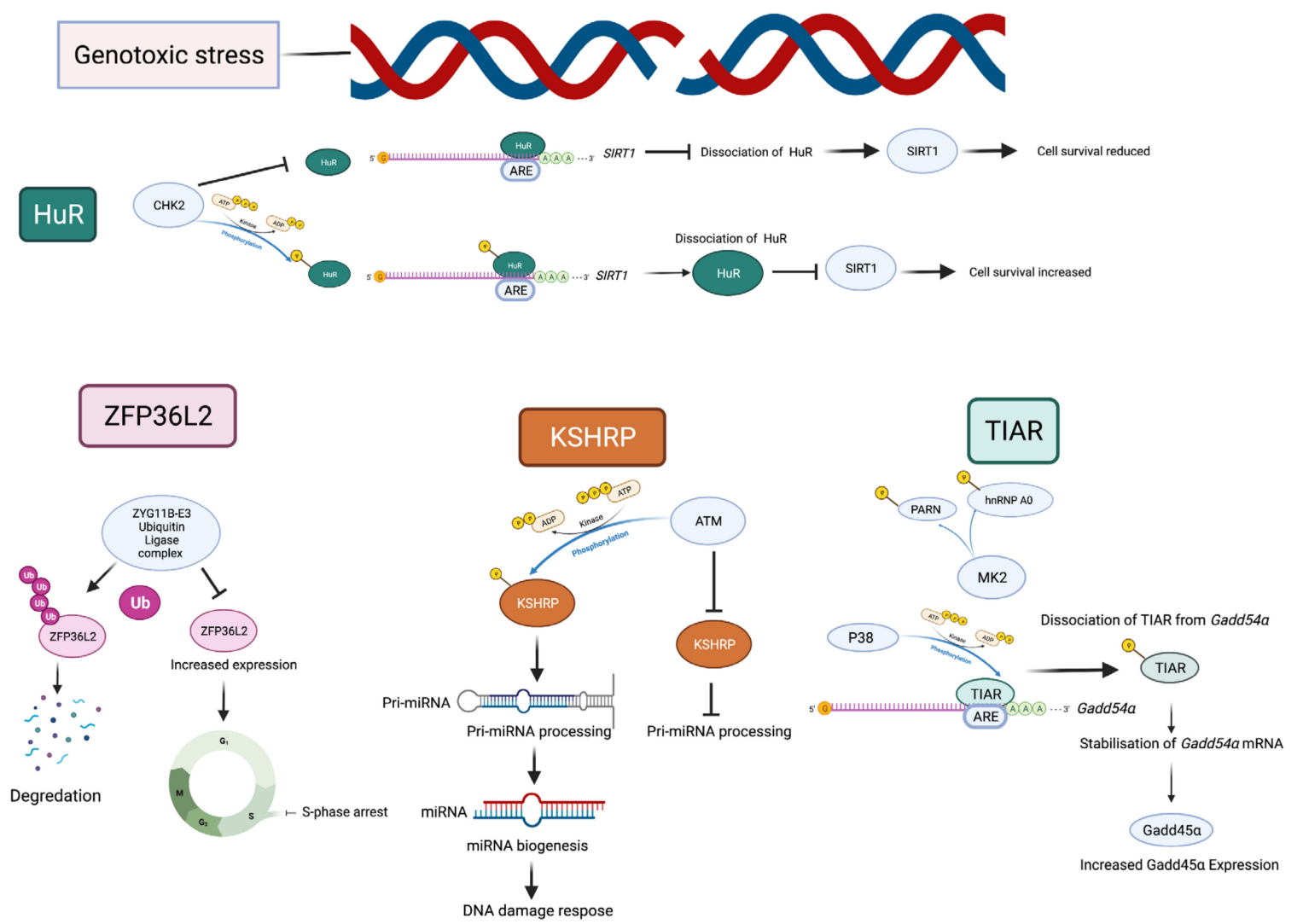

Figure 3. AU-RBPs exhibit post-translational modifications in response to genotoxic stress. Genotoxic stress results in post-translational modifications of AU-RPBs influencing their activity. The AU-RBP $\mathrm{HuR}$ is targeted for phosphorylation by CHK2 resulting in its dissociation from SIRT1 inhibiting SIRT1 expression and increasing cell survival. When CHK2 mediated phosphorylation of HuR is blocked, HuR remains bound to SIRT1 resulting in increased SIRT1 expression and decreasing cell survival. KSHRP is phosphorylated by ATM promoting its role in Pri-miRNA processing and miRNA biogenesis, which may have a role in the DDR. Concomitant phosphorylation of AU-RBP TIAR by p38 and PARN and hnRNP A0 by MK2 is involved in TIARs dissociation from Gadd45 $\alpha$ resulting in Gadd45 $\alpha$ 's stabilization and increasing GADD45 $\alpha$ expression. Polyubiquitination of ZFP36L2 by ZYG11B-E3 ubiquitin ligase complex regulate ZFP36L2 expression levels ensuring its degradation. Genotoxic stress increases ZFP36L2 resulting in S-phase arrest which may be attributed to a reduction in polyubiquitination of ZFP36L2.

The AU-RBP, KH-type splicing regulatory protein (KHSRP) was reported to be targeted for phosphorylation by ATM in response to DNA double-strand breaks induced by the radiomimetic drug neocarzinostatin (NCS) [69]. Immunoprecipitated KHSRP in human ATM proficient and deficient fibroblast cells demonstrated KHSRP phosphorylation in ATM proficient cells, whereas no notable phosphorylation of KHSRP was detected in cells deficient for ATM. Furthermore, mutations to three putative ATM phosphorylation sites of KHSRP at Ser 132 (S132), Ser 274 (S274) and Ser 670 (S670) were revealed to impact KHSRP phosphorylation in ATM proficient cells. Specifically, mutations to S274 and S670 diminished ATM-mediated KHSRP phosphorylation greater than that of S132 mutations, implicating S274 and S670 as major ATM target residues [69]. Interestingly, ATM phosphorylation of KHSRP was shown to promote KHSRP activity, enhancing primary-microRNA (pri-miRNA) interactions in response to DNA damage and mutations to KHSRP's ATM phosphorylation sites impaired its activity in miRNA biogenesis (Figure 3). Additionally, 
RNA-CHIP (chromatin immunoprecipitation) assays demonstrated that ATM phosphorylation is essential for mediating KHSRP interactions with pri-miRNAs following DNA damage, a process that was impaired following mutations to KHSRP's ATM phosphorylation sites [69]. ATM-mediated phosphorylation of KHSRP is therefore essential for its role in pri-miRNA processing in response to DNA damage, which has been reported to be important in DNA repair (Figure 3) [107,108].

The AU-RBP ZFP36L2 was reported to be regulated in a cell cycle-dependent manner and accumulates in the mitotic phase of the cell cycle [86]. Downregulation of ZFP36L2 expression in the cell interphase was shown to be mediated post-translationally by polyubiquitination of the protein by ZYG11B-E3 ubiquitin ligase complex, resulting in its subsequent degradation. Furthermore, in cisplatin-treated cells, ZFP36L2 expression was increased and mediated cell $S$ phase arrest protected cells from dying following cisplatin-induced DNA damage, implying that ZFP36L2 plays a role in controlling $S$ phase transition under conditions of genomic instability [86].

\section{Subcellular Localisation of AU-RBPs in Response to DNA Damage}

Nucleocytoplasmic shuttling activity elicited by AU-RBPs may partially explain their multifaceted nature and emergence as key players in maintaining genome integrity [109]. Post-transcriptional modulation of gene expression largely occurs in the nucleus and cytosol (as reviewed in [110]). DNA damage can result in changes in AU-RBP localisation and such changes can determine the interactions and activities of AU-RBPs (Figure 4). Well characterised AU-RBPs, such as the ZFP36 family, contain both nuclear localisation sequences (NLS) and functional nuclear export sequences (NES), facilitating nuclear import and export, respectively $[109,111]$. Interestingly, it was reported that the AU-RBP ZFP36 acted as a transcriptional co-repressor of p65/NF- $\mathrm{KB}$ [112]. Furthermore, ZFP36 was shown to interact with the retroviral transcriptional activator Tax protein; this association with Tax induced nuclear accumulation of ZFP36 and indirectly increased TNF $\alpha$ expression (Figure 4) [113]. A recent report provided evidence that the accumulation of ZFP36L1 in the nucleus is cell cycle-dependent, peaks at G1/S and is dependent on the protein's C-terminal serine-rich cluster [114].

The AU-RBP HuR has been shown to exhibit changes in subcellular localisation in a cell cycle-dependent manner. During the G1 phase, HuR was found to be primarily nuclear, whereas, in S and G2, HuR was located primarily in the cytoplasm in order to regulate the stability and translation of mRNA targets $[63,115]$. In response to UV damage, HuR subcellular localisation has been shown to be regulated in a CDK1 dependent manner. Specifically, cells exposed to UV activate ATR enabling nuclear-cytoplasmic shuttling of HuR [116]. ATR phosphorylation of CDK1 promotes its disassociation from HuR, enabling translocation to the cytoplasm where HuR binds to mRNA target p21/CDKN1A, reducing its turnover [116]. Recently, ATM/p38 signaling was shown to promote the cytoplasmic translocation of $\mathrm{HuR}$ from the nucleus in response to IR, stabilising mitochondrial transcription factor A (TFAM) mRNA [55].

HuR has also been reported to mediate efficient DNA repair through post-transcriptional regulation of Poly (ADP-ribose) glycohydrolase (PARG) mRNA [56]. In pancreatic ductal cancer cells treated with PARP inhibitors translocation of HuR from the nucleus to the cytoplasm is stimulated, promoting stabilisation of PARG mRNA. PARG coordinates efficient repair of DNA lesions together with Poly (ADP-ribose) polymerase 1 (PARP-1). Specifically, HuR stabilisation of PARG promotes the removal of Poly (ADP-ribose) (PAR) moieties from PARP-1 thereby initiating replication fork restart and DDR resolution (Figure 4) $[117,118]$. HuR silencing resulted in decreased mRNA half-life and expression of PARG, as well as increased susceptibility to double-strand breaks in the presence of PARP inhibitors veliparib and olaparib. Furthermore, diminishing PARG levels through HuR silencing was demonstrated to impact PARP-1 release from chromatin, suggesting deficiencies in the HuR/PARG axis increase PARP-1 accumulation on chromatin inhibiting the efficiency of DNA repair [56]. 


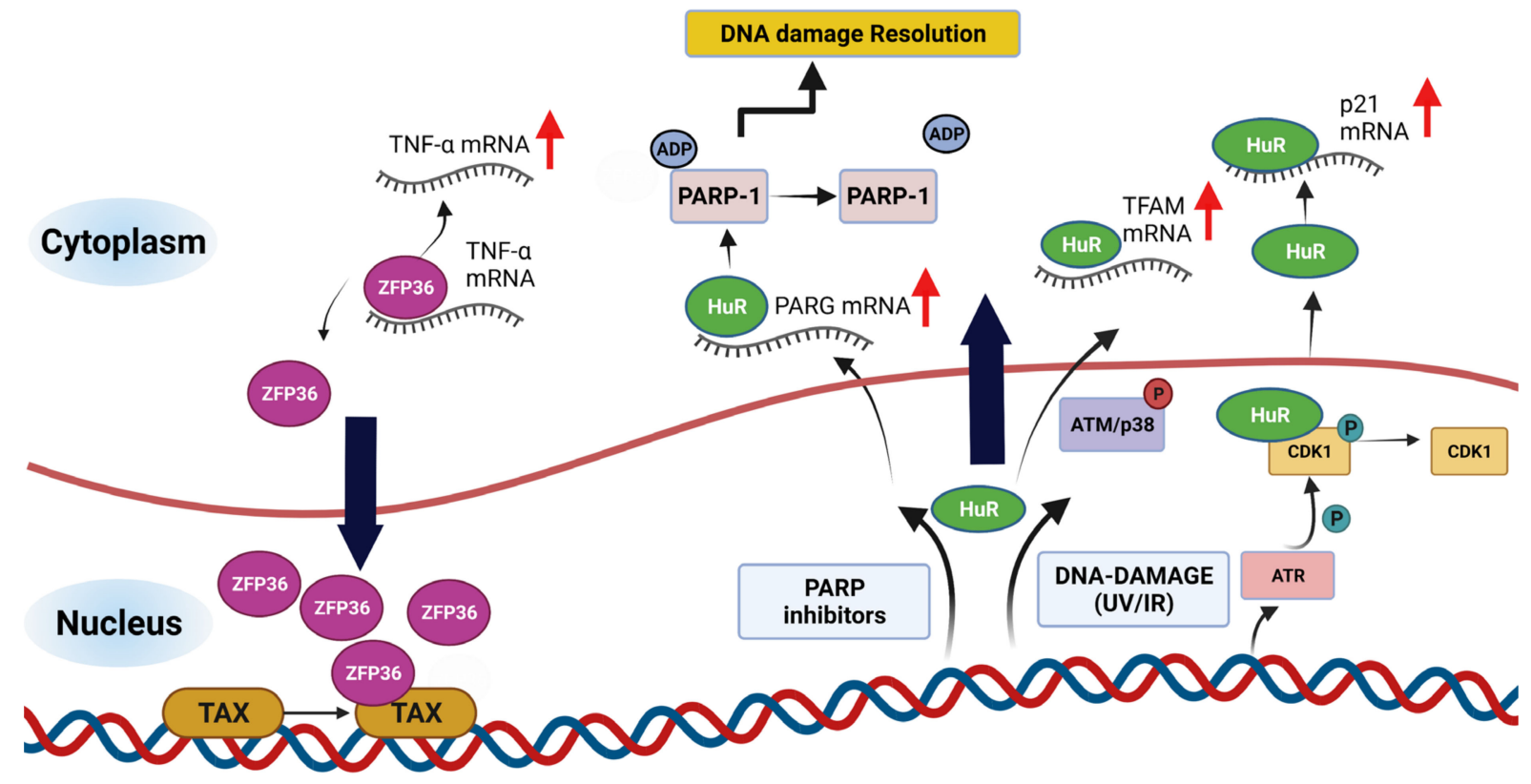

Figure 4. Subcellular environment dictates nucleocytoplasmic shuttling of AU-RBPs. In the nucleus, interaction of AU-RBP ZFP36 with retroviral transcriptional activator Tax protein results in shuttling of ZFP36 inside the nucleus and indirectly increase of TNF $\alpha$ mRNA in the cytoplasm. AU-RBP HuR translocates to cytoplasm in response to DNA-damage, resulting HuR binding and stabilisation of its mRNA targets including TFAM, PARG, CDKN1A. Bold black arrows indicate mobility of the AU-RBPs across the cellular compartments shown and red arrows indicate increased stability of the mRNAs.

TIA-1 and TIAR also shuttle between the nucleus and cytoplasm and both play an important role in alternative splicing of pre-mRNAs in the nucleus [119]. TIAR was also reported to relocate from the nucleus to the cytoplasm in response to Fas-mediated apoptotic cell death [120]. It has also been reported that both TIA-1 and TIAR can bind to DNA with high affinity; they probably shuttle between RNA and DNA ligands in carrying out their cellular functions [121].

\section{AU-RBPs at the Crossroads of DNA Repair and Genome Maintenance}

Selected AU-RBPs (Table 1) have recently emerged as key mediators of DNA repair, eliciting canonical roles through mRNA regulation and non-canonical direct interactions at the sites of DNA damage where they are required for efficient DNA repair through regulating distinct repair pathways.

The AU-RBP AUF1 has been reported to localise at sites of DNA damage, mediating the efficient repair of DNA lesions, suggesting that these interactions can be achieved independently of mRNA interactions [48]. In proteomic screens for proteins involved in DNA-end resection, a process that produces ssDNA tails required for the invasion of a complementary DNA strand within the HR pathway [48,122], AUF1 was found to bind structures that mimic DNA end-resection intermediates composed of protruding nucleotide ends independent of RPA complexes [48]. Furthermore, AUF1 was reported to bind chromatin DNA purified from Hela cells, without AUF1's RNA recognition motif involvement, suggesting that binding to DNA, as well as chromatin structures, is independent of AUF1 RNA regulatory mechanisms [48]. Intriguingly, CPT treatment in AUF1-depleted cells markedly reduced the efficiency of DNA end resection and RPA binding in comparison to control cells, while chromatin IP (ChIP) of FLAG-tagged AUF1 transfected into engineered Hela cells, expressing inducible AsiSI endonuclease to control DSBs in vivo, demonstrating the increased presence of AUF1 proximal to DSB sites $[48,123]$. Finally, AUF1 downregulation was demonstrated to reduce HR efficiency by approximately $50 \%$ in comparison to 
control cells, highlighting that AUF1 may indeed be involved in mediating efficient DNA repair through the HR pathway [48]. AUF1 has also been reported to bind factors involved in NHEJ. Liquid chromatography mass spectrometry analysis of immunoprecipitates, obtained from oral cancer cell lines SCC4 and MDA1986, demonstrated interactions with X-ray repair cross-complementing protein 5 and 6 (XRCC5 and 6 also known as Ku70 and $\mathrm{Ku} 80$ ) that bind broken DNA ends and mediate repair through NHEJ (Figure 1) [124,125].

R-loops form through the hybridisation of nascent RNA with a template DNA strand, displacing the non-template strand into long stretches of ssDNA, forming non-canonical RNA-DNA hybrid structures (Figure 5) [126,127]. R loops play an important role in transcription termination, immunoglobulin class switching, mitochondrial DNA replication, chromatin modification, and telomere regulation dynamics [128]. However, unscheduled and unprocessed R-loop formation can prove deleterious to genome integrity, inducing hypermutagenesis due to the exposed ssDNA becoming susceptible to DNA modifying enzymes such as activation-induced cytidine deaminase (AID) and increasing the occurrence of DNA breaks as a result of replication stress or replication fork collision with the transcription machinery (transcription-replication conflicts) [129-132]. Importantly, the nascent RNA is fundamental to the formation of R-loops; dysfunction in factors involved in RNA biogenesis and processing induce the formation of R-loops [133-135]. Such factors may include selected AU-RBPs that may protect the nascent RNA through direct or indirect interactions, preventing its hybridization with the template DNA strand. A recent study utilising mass spectrometry analysis presented evidence for the AU-RBPs HuR and AUF1 being associated with the DNA: RNA hybrid-interactome [53]. Furthermore, in vitro studies revealed that depletion of AUF1 resulted in a defective DNA damage response and also increased the number of R-loops in human Hela cells following DNA damage (Figure 5) [48]. Overexpression of the Rnase H1 led to a reversal of the phenotype associated with AUF1 depletion, suggesting a role for the resolution of R-loops in rescuing a defective DDR [48]. These results indicate that AU-RBPs may play a role in deterring R-loop formation similar to what has been reported for other RBPs [46,136].

Evidence suggests that some genomic regions known as common fragile sites (CFS) are susceptible to gaps and breaks (termed 'expression') in response to replication stress and could be a source of genomic instability present in some cancers [137]. In vitro, CFSs are usually stable under unperturbed growth conditions and can become expressed following mild replication stress when treated with low doses of aphidicolin or in vivo by dysfunctional oncogene activation. Furthermore, CFS are prone to mutations and are susceptible to sister chromatid exchange exhibiting translocation and deletions [138]. Breakpoints in tumours have been mapped to CFS and result in the loss of tumour suppressor genes or amplification of oncogenes, which are hallmarks of cancers $[139,140]$. Unlike CFS present in all individuals, a separate classification of fragile sites known as rare fragile sites exists in less than $5 \%$ of the population [141]. Furthermore, it has also been determined that replication blocks at CFS loci, as a result of transcription replication conflicts, may lead to the formation of R-loops, leading to breaks, suggesting that the modulation of R-loops is essential to maintaining CFS stability [142]. Interestingly, four of the eight AU-RBP genes discussed in this current review (Table 1) are located within known fragile sites [143]. Specifically, the ZFP36 gene is mapped to the common fragile site FRA19A, and the ZFP36L1 gene is located on the common fragile site FRA14C. Furthermore, TIAR and $H u R$ genes are mapped to rare fragile sites FRA10A and FRA19B, respectively. The occurrence of ZFP36, ZFP36L1, TIAR, and $H u R$ at fragile sites is intriguing; however, the significance of this in relation to $\mathrm{R}$ loop formation and genome integrity is currently unknown. Intriguingly, interstitial deletions in $\operatorname{del}(14)(q)$ close to the ZFP36l1 locus are a recurrent aberration in B cell malignancies [144]. 


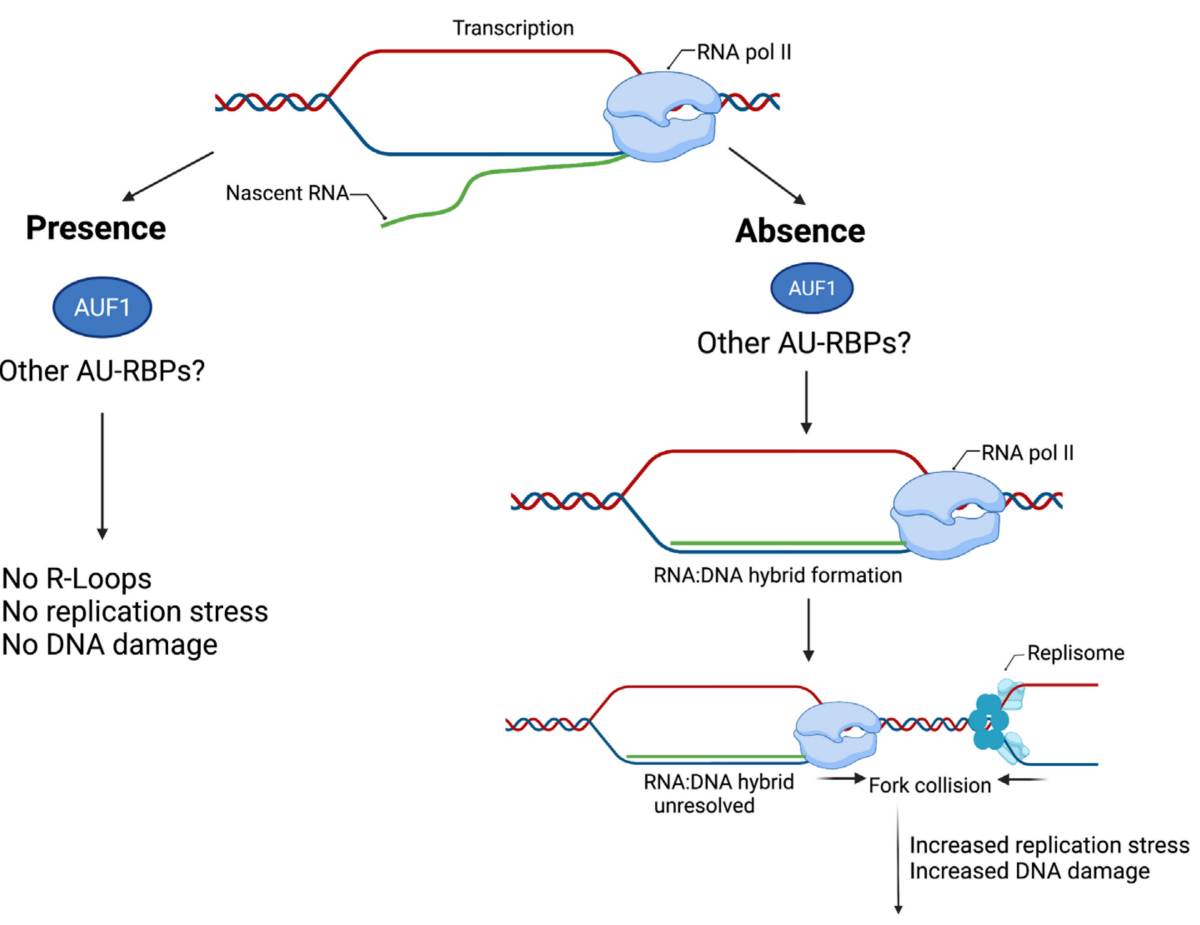

Genomic instability

Figure 5. Potential roles of AU-RBPs in preventing R-loop formation in response to replication stress. During the process of transcription by RNA polymerase II (RNA pol II), the nascent RNA is prevented from hybridizing with the template strand DNA strand (RNA: DNA hybrid) in the presence of AUF1 and possibly other AU-RBPs. Therefore preventing the formation of R-loops that cause replication stress and DNA damage. In the absence of AUF1 and possibly other AU-RBPs the nascent RNA can hybridise with the template strand and displace the non-template strand into a long stretch of ssDNA forming an R-loop structure. Unresolved R-loops can cause transcription and replication fork collisions, resulting in increased replication stress and DNA damage that compromise genomic instability.

\section{AU-RBPs in Cancer}

Multiple processes are employed by AU-RBPs to maintain genome integrity (Table 1); therefore, it is unsurprising that dysfunctions of AU-RPBs are associated with various diseases, including cancer. Numerous studies have provided a large body of evidence for a variety of roles of AU-RBPs in different cancers and the evidence presented here is selected information rather than an exhaustive survey (Figure 6) (Table 1). AUF1 is overexpressed in esophageal squamous cell carcinoma patient tissue samples [49] and AUF1 overexpression has also been shown to promote colorectal cancer progression and is an indicator of poor prognosis in this disease [50]. HuR is elevated in clinical ductal invasive carcinoma (DIC) and ductal carcinoma in situ (DCIS) breast cancer samples $[64,65]$. Elevated cytoplasmic expression of HuR was found to be a possible indicator of poor prognosis in breast cancer patients that received paclitaxel- and anthracycline-based neoadjuvant chemotherapy (NACT) [66]. Furthermore, HuR has been reported to be an oncogenic driver for malignant peripheral nerve sheath tumours (MPNSTs) [67]. KHSRP has been reported to be critical for the growth of melanoma cells [70], and is upregulated in lung cancers [71,72] and colorectal cancer [73]. TIA1 and TIAR are mutated across multiple cancer types and probably function as tumour suppressors [94,145]. Low expression of TIA1 and TIAR correlates with poor prognosis in patients with lung squamous cell carcinoma [75]. 


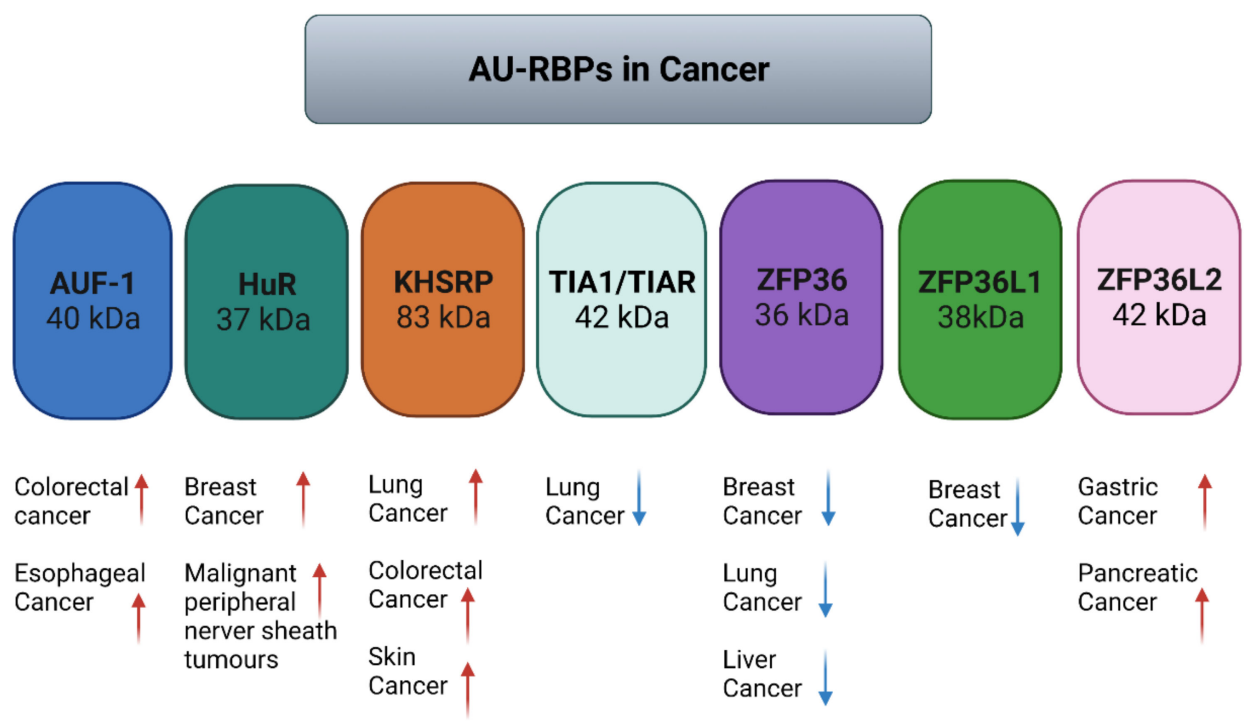

Figure 6. AU-RBPs are aberrantly expressed in various kinds of cancer, where AUF1, HuR, KHSRP and ZFP36L2 are found to be mostly upregulated and TIA1, ZFP36 and ZFP36L1 are found to be downregulated in breast, lung and liver cancers.

With regard to the ZFP36 AU-RBP gene family, perhaps the strongest evidence for a link with tumourigenesis has come from the observation that deletion of both zfp36pl1 and zfp36l2 in mice leads to T lymphoblastic leukaemia [82]. Many studies in human cancers have also reported that ZFP36 is underexpressed in different cancers [77-80]. A general paradigm has emerged consistent with ZFP36 family proteins functioning as tumour suppressor genes. Genome-wide sequencing studies that identified ZFP36L1 as a driver gene in breast cancer [83] and multiple myeloma [84], identifying inactivating mutations in the ZFP36L1 gene, provided more recent evidence supporting this hypothesis. Based on these observations, a few studies have also reported strategies for inducing ZFP36 family protein expression as novel anti-cancer therapies [146,147]. However, although ZFP36L1 has generally been considered a tumour suppressor gene, in acute myeloid leukaemia cells carrying the AML-ETO1 translocation, ZFP36L1 is overexpressed and is associated with increased proliferation and inhibition of differentiation [148]. More recently, CRISPR Cas9 knockout of ZFP36L1 in chronic myeloid leukaemia cells lines reduced cell growth [85]. These results highlight possible cell context-specific effects of ZFP36L1 on cell growth and proliferation. Like ZFP36L1, ZFP36L2 has also been indicated to play oncogenic and tumour suppressive roles in different cancer types. Specifically, ZFP36L2 was indicated as a tumour suppressor through pan-cancer whole-genome sequencing techniques highlighting ZFP36L2 to be significantly mutated in metastatic tumours [89]. Conversely, ZFP36L2 has been reported to have oncogenic activity in gastric cancer [87] and pancreatic cancer [88], suggesting that ZFP36L2 may adopt cell type-specific functions of which the biological relevance should be further investigated.

\section{Conclusions and Future Directions}

Hitherto, it has been assumed that the important biological role(s) of AU-RBPs (Table 1) are principally related to their well-characterized functions in post-transcriptionally regulating mRNAs by binding to AREs in the $3^{\prime}$ UTR of certain mRNAs and mediating either degradation or localization and/or effecting mRNA translation. However, emerging evidence presented here has also highlighted the multi-faceted roles of AU-RBPs (Table 1), particularly those involved in maintaining genome integrity, which may also be important in normal biological processes. This is highlighted by their roles in post-transcriptional regulation of key regulators and mediators of the DDR through canonical mRNA binding of ARE regions in the $3^{\prime} \mathrm{UTR}$. Furthermore, non-canonical protein-protein interactions, 
whereby AU-RBPs are direct targets of DDR components for PTMs, also influence their subsequent activity in response to genotoxicity. Nucleocytoplasmic shuttling capabilities of all the AU-RBPs described in this review is an intriguing area for further study, although, most of the nucleocytoplasmic shuttling of AU-RBPs have been reported to maintain genome integrity through mRNA interactions. A number of AU-RBPs described here can also bind DNA, which presents the prospect that they may also cooperate in DNA repair, as has been discussed for the AU-RBP AUF1. Therefore, it would be of interest to gain further insight into the capabilities of AU-RBPs to localize to sites of DNA damage. There is increasing evidence that dysfunctional AU-RBPs are associated with cancer. Further understanding of the molecular mechanisms and signaling involved with these multi-functional AU-RBPs may elucidate additional insights into their links to genome integrity and may uncover novel therapeutic strategies for targeting these proteins in cancer.

Author Contributions: Conceptualization, R.K., J.J.M. and K.S.; writing-original draft preparation, A.S. and K.S.; writing-review and editing, A.S., V.T., N.S.S., N.B., R.K., J.J.M. and K.S.; visualization, A.S. and V.T.; supervision, J.J.M. and K.S. All authors have read and agreed to the published version of the manuscript.

Funding: This research is supported by the Children with Cancer UK Grant (PGTaSFA \100027) awarded for the project "An exploratory pilot study to enable development of improved drug therapy for childhood bone cancer".

Acknowledgments: We would like to thank the genome engineering lab members for stimulating discussion and critical reading of the manuscript. We gratefully acknowledge the constant support of alumni donor Raj Sitlani, IS Prime Limited to the research of genome engineering laboratory. We apologize for any important work that was not cited in this article owing to space limitations. All figures were created with BioRender.com.

Conflicts of Interest: The authors declare no conflict of interest.

\section{References}

1. Lindahl, T.; Barnes, D.E. Repair of Endogenous DNA Damage. Cold Spring Harb. Symp. Quant. Biol. 2000, 65, 127-133. [CrossRef] [PubMed]

2. Tubbs, A.; Nussenzweig, A. Endogenous DNA Damage as a Source of Genomic Instability in Cancer. Cell 2017, 168, 644-656. [CrossRef]

3. Khanna, K.K.; Jackson, S.P. DNA Double-Strand Breaks: Signaling, Repair and the Cancer Connection. Nat. Genet. 2001, 27, 247-254. [CrossRef] [PubMed]

4. Aguilera, A.; García-Muse, T. Causes of Genome Instability. Annu. Rev. Genet. 2013, 47, 1-32. [CrossRef]

5. Hanahan, D.; Weinberg, R.A. Hallmarks of Cancer: The next Generation. Cell 2011, 144, 646-674. [CrossRef]

6. Hoch, N.C.; Hanzlikova, H.; Rulten, S.L.; Tétreault, M.; Komulainen, E.; Ju, L.; Hornyak, P.; Zeng, Z.; Gittens, W.; Rey, S.A.; et al. XRCC1 Mutation Is Associated with PARP1 Hyperactivation and Cerebellar Ataxia. Nature 2017, 541, 87-91. [CrossRef]

7. Negrini, S.; Gorgoulis, V.G.; Halazonetis, T.D. Genomic Instability an Evolving Hallmark of Cancer. Nat. Rev. Mol. Cell Biol. 2010, 11, 220-228. [CrossRef] [PubMed]

8. Zhou, B.B.S.; Elledge, S.J. The DNA Damage Response: Putting Checkpoints in Perspective. Nature 2000, 11, 220-228. [CrossRef] [PubMed]

9. Blackford, A.N.; Jackson, S.P. ATM, ATR, and DNA-PK: The Trinity at the Heart of the DNA Damage Response. Mol. Cell 2017, 66, 801-817. [CrossRef]

10. Smith, J.; Mun Tho, L.; Xu, N.; Gillespie, D.A. The ATM-Chk2 and ATR-Chk1 pathways in DNA damage signaling and cancer. In Advances in Cancer Research; Elsevier: Amsterdam, The Netherlands, 2010.

11. Álvarez-Quilón, A.; Serrano-Benítez, A.; Lieberman, J.A.; Quintero, C.; Sánchez-Gutiérrez, D.; Escudero, L.M.; Cortés-Ledesma, F. ATM Specifically Mediates Repair of Double-Strand Breaks with Blocked DNA Ends. Nat. Commun. 2014, 5, 3347. [CrossRef]

12. Haahr, P.; Hoffmann, S.; Tollenaere, M.A.X.; Ho, T.; Toledo, L.I.; Mann, M.; Bekker-Jensen, S.; Räschle, M.; Mailand, N. Activation of the ATR Kinase by the RPA-Binding Protein ETAA1. Nat. Cell Biol. 2016, 18, 1196-1207. [CrossRef] [PubMed]

13. Maréchal, A.; Zou, L. DNA Damage Sensing by the ATM and ATR Kinases. Cold Spring Harb. Perspect. Biol. 2013, 5, a012716. [CrossRef] [PubMed]

14. Jackson, S.P. Sensing and Repairing DNA Double-Strand Breaks. Carcinogenesis 2002, 23, 687-696. [CrossRef]

15. Kotsantis, P.; Petermann, E.; Boulton, S.J. Mechanisms of Oncogene-Induced Replication Stress: Jigsaw Falling into Place. Cancer Discov. 2018, 8, 537-555. [CrossRef] [PubMed]

16. Kastan, M.B.; Bartek, J. Cell-Cycle Checkpoints and Cancer. Nature 2004, 432, 316-323. [CrossRef] 
17. Bartek, J.; Lukas, J. DNA Damage Checkpoints: From Initiation to Recovery or Adaptation. Curr. Opin. Cell Biol. 2007, 19, 238-245. [CrossRef] [PubMed]

18. Jackson, S.P.; Bartek, J. The DNA-Damage Response in Human Biology and Disease. Nature 2009, 461, 1071-1078. [CrossRef] [PubMed]

19. Huen, M.S.Y.; Chen, J. The DNA Damage Response Pathways: At the Crossroad of Protein Modifications. Cell Res. 2008, 18, 8-16. [CrossRef]

20. Matsuoka, S.; Ballif, B.A.; Smogorzewska, A.; McDonald, E.R.; Hurov, K.E.; Luo, J.; Bakalarski, C.E.; Zhao, Z.; Solimini, N.; Lerenthal, Y.; et al. ATM and ATR Substrate Analysis Reveals Extensive Protein Networks Responsive to DNA Damage. Science 2007, 316, 1160-1166. [CrossRef]

21. Dietlein, F.; Thelen, L.; Reinhardt, H.C. Cancer-Specific Defects in DNA Repair Pathways as Targets for Personalized Therapeutic Approaches. Trends Genet. 2014, 30, 326-339. [CrossRef]

22. Kleiman, F.E.; Manley, J.L. The BARD1-CstF-50 Interaction Links MRNA $3{ }^{\prime}$ End Formation to DNA Damage and Tumor Suppression. Cell 2001, 104, 743-753. [CrossRef]

23. Mirkin, N.; Fonseca, D.; Mohammed, S.; Cevher, M.A.; Manley, J.L.; Kleiman, F.E. The $3^{\prime}$ Processing Factor CstF Functions in the DNA Repair Response. Nucleic Acids Res. 2008, 36, 1792-1804. [CrossRef]

24. Fan, J.; Yang, X.; Wang, W.; Wood, W.H.; Becker, K.G.; Gorospe, M. Global Analysis of Stress-Regulated MRNA Turnover by Using CDNA Arrays. Proc. Natl. Acad. Sci. USA 2002, 99, 10611-10616. [CrossRef]

25. Braunstein, S.; Badura, M.L.; Xi, Q.; Formenti, S.C.; Schneider, R.J. Regulation of Protein Synthesis by Ionizing Radiation. Mol. Cell. Biol. 2009, 29, 5645-5656. [CrossRef] [PubMed]

26. Kruiswijk, F.; Yuniati, L.; Magliozzi, R.; Low, T.Y.; Lim, R.; Bolder, R.; Mohammed, S.; Proud, C.G.; Heck, A.J.R.; Pagano, M.; et al Coupled Activation and Degradation of EEF2K Regulates Protein Synthesis in Response to Genotoxic Stress. Sci. Signal. 2012, 5 , ra40. [CrossRef]

27. Dutertre, M.; Lambert, S.; Carreira, A.; Amor-Guéret, M.; Vagner, S. DNA Damage: RNA-Binding Proteins Protect from near and Far. Trends Biochem. Sci. 2014, 39, 141-149. [CrossRef]

28. Powley, I.R.; Kondrashov, A.; Young, L.A.; Dobbyn, H.C.; Hill, K.; Cannell, I.G.; Stoneley, M.; Kong, Y.W.; Cotes, J.A.; Smith, G.C.M.; et al. Translational Reprogramming Following UVB Irradiation Is Mediated by DNA-PKcs and Allows Selective Recruitment to the Polysomes of MRNAs Encoding DNA Repair Enzymes. Genes Dev. 2009, 23, 1207-1220. [CrossRef]

29. Badura, M.; Braunstein, S.; Zavadil, J.; Schneider, R.J. DNA Damage and EIF4G1 in Breast Cancer Cells Reprogram Translation for Survival and DNA Repair MRNAs. Proc. Natl. Acad. Sci. USA 2012, 109, 18767-18772. [CrossRef] [PubMed]

30. Kumaraswamy, S.; Chinnaiyan, P.; Shankavaram, U.T.; Lü, X.; Camphausen, K.; Tofilon, P. Radiation-Induced Gene Translation Profiles Reveal Tumor Type and Cancer-Specific Components. Cancer Res. 2008, 68, 3819-3826. [CrossRef] [PubMed]

31. Audic, Y.; Hartley, R.S. Post-Transcriptional Regulation in Cancer. Biol. Cell 2004, 96, 479-498. [CrossRef]

32. Pickering, B.M.; Willis, A.E. The Implications of Structured 5' Untranslated Regions on Translation and Disease. Semin. Cell Dev. Biol. 2005, 16, 39-47. [CrossRef] [PubMed]

33. Bakheet, T.; Williams, R.G.; Khabar, A. ARED 3.0: The Large and Diverse AU-Rich Transcriptome. Nucleic Acids Res. 2006, 34 , D111-D114. [CrossRef]

34. Baou, M.; Jewell, A.; Murphy, J.J. TIS11 Family Proteins and Their Roles in Posttranscriptional Gene Regulation. J. Biomed. Biotechnol. 2009, 2009, 1-11. [CrossRef]

35. Lunde, B.M.; Moore, C.; Varani, G. RNA-Binding Proteins: Modular Design for Efficient Function. Nat. Rev. Mol. Cell Biol. 2007, 8 , 479-490. [CrossRef] [PubMed]

36. Valverde, R.; Edwards, L.; Regan, L. Structure and Function of KH Domains. FEBS J. 2008, 275, 2712-2726. [CrossRef]

37. Katahira, M.; Miyanoiri, Y.; Enokizono, Y.; Matsuda, G.; Nagata, T.; Ishikawa, F.; Uesugi, S. Structure of the C-Terminal RNABinding Domain of HnRNP D0 (AUF1), Its Interactions with RNA and DNA, and Change in Backbone Dynamics upon Complex Formation with DNA. J. Mol. Biol. 2001, 311, 973-988. [CrossRef]

38. Castello, A.; Fischer, B.; Frese, C.K.; Horos, R.; Alleaume, A.M.; Foehr, S.; Curk, T.; Krijgsveld, J.; Hentze, M.W. Comprehensive Identification of RNA-Binding Domains in Human Cells. Mol. Cell 2016, 63, 696-710. [CrossRef] [PubMed]

39. Finn, R.D.; Mistry, J.; Tate, J.; Coggill, P.; Heger, A.; Pollington, J.E.; Gavin, O.L.; Gunasekaran, P.; Ceric, G.; Forslund, K.; et al. The Pfam Protein Families Database. Nucleic Acids Res. 2009, 38, D211-D222. [CrossRef]

40. Wurth, L. Versatility of RNA-Binding Proteins in Cancer. Comp. Funct. Genom. 2012, 2012, 1-11. [CrossRef] [PubMed]

41. Glisovic, T.; Bachorik, J.L.; Yong, J.; Dreyfuss, G. RNA-Binding Proteins and Post-Transcriptional Gene Regulation. FEBS Lett. 2008, 582, 1977-1986. [CrossRef]

42. Conlon, E.G.; Manley, J.M. RNA-Binding Proteins in Neurodegeneration: Mechanisms in Aggregate. Genes Dev. 2017, 31, 1509-1528. [CrossRef]

43. Lukong, K.E.; Chang, K.W.; Khandjian, E.W.; Richard, S. RNA-Binding Proteins in Human Genetic Disease. Trends Genet. 2008, 24, 416-425. [CrossRef]

44. Pereira, B.; Billaud, M.; Almeida, R. RNA-Binding Proteins in Cancer: Old Players and New Actors. Trends Cancer 2017, 3, 506-528. [CrossRef] [PubMed] 
45. Chang, Y.; Mai, R.; Fang, W.; Lin, C.; Chiu, C. YB-1 Disrupts Mismatch Repair Complex Formation, Interferes with MutS $\alpha$ Recruitment on Mismatch and Inhibits Mismatch Repair through Interacting with PCNA. Oncogene 2013, 33, 5065-5077. [CrossRef] [PubMed]

46. Gorthi, A.; Romero, J.C.; Loranc, E.; Cao, L.; Lawrence, L.A.; Goodale, E.; Iniguez, A.B.; Bernard, X.; Masamsetti, V.P.; Roston, S.; et al. EWS-FLI1 Increases Transcription to Cause R-Loops and Block BRCA1 Repair in Ewing Sarcoma. Nature 2018, 555, 387-391. [CrossRef] [PubMed]

47. Polo, S.E.; Blackford, A.N.; Chapman, J.R.; Baskcomb, L.; Gravel, S.; Rusch, A.; Thomas, A.; Blundred, R.; Smith, P.; Kzhyshkowska, J.; et al. Regulation of DNA-End Resection by HnRNPU-like Proteins Promotes DNA Double-Strand Break Signaling and Repair. Mol. Cell 2012, 45, 505-516. [CrossRef]

48. Alfano, L.; Caporaso, A.; Altieri, A.; Dell'Aquila, M.; Landi, C.; Bini, L.; Pentimalli, F.; Giordano, A. Depletion of the RNA Binding Protein HNRNPD Impairs Homologous Recombination by Inhibiting DNA-End Resection and Inducing R-Loop Accumulation. Nucleic Acids Res. 2019, 47, 4068-4085. [CrossRef]

49. Gao, Y.; Wang, W.; Cao, J.; Wang, F.; Geng, Y.; Cao, J.; Xu, X.; Zhou, J.; Liu, P.; Zhang, S. Upregulation of AUF1 Is Involved in the Proliferation of Esophageal Squamous Cell Carcinoma through GCH1. Int. J. Oncol. 2016, 49, 2001-2010. [CrossRef]

50. Tian, X.; Li, J.; Liu, T.; Li, D.; Wang, J.; Zhang, H.; Deng, Z.; Chen, F.; Cai, J. The Overexpression of AUF1 in Colorectal Cancer Predicts a Poor Prognosis and Promotes Cancer Progression by Activating ERK and AKT Pathways. Cancer Med. 2020, $9,8612$. [CrossRef]

51. Andrade, D.; Mehta, M.; Griffith, J.; Oh, S.; Corbin, J.; Babu, A.; De, S.; Chen, A.; Zhao, Y.D.; Husain, S.; et al. HuR Reduces Radiation-Induced DNA Damage by Enhancing Expression of ARID1A. Cancers 2019, 11, 2014. [CrossRef] [PubMed]

52. Ryu, I.; Park, Y.; Seo, J.-W.; Park, O.H.; Ha, H.; Nam, J.-W.; Kim, Y.K. HuR Stabilizes a Polyadenylated Form of ReplicationDependent Histone MRNAs under Stress Conditions. FASEB J. 2019, 33, 2680-2693. [CrossRef]

53. Cristini, A.; Groh, M.; Kristiansen, M.S.; Gromak, N. RNA/DNA Hybrid Interactome Identifies DXH9 as a Molecular Player in Transcriptional Termination and R-Loop-Associated DNA Damage. Cell Rep. 2018, 23, 1891-1905. [CrossRef] [PubMed]

54. Lee, J.H.; Jung, M.; Hong, J.; Kim, M.K.; Chung, I.K. Loss of RNA-Binding Protein HuR Facilitates Cellular Senescence through Posttranscriptional Regulation of TIN2 MRNA. Nucleic Acids Res. 2018, 46, 4271-4285. [CrossRef]

55. Zhang, R.; Wang, J. HuR Stabilizes TFAM MRNA in an ATM/P38-Dependent Manner in Ionizing Irradiated Cancer Cells. Cancer Sci. 2018, 109, 2446-2457. [CrossRef]

56. Chand, S.N.; Zarei, M.; Schiewer, M.J.; Kamath, A.R.; Romeo, C.; Lal, S.; Cozzitorto, J.A.; Nevler, A.; Scolaro, L.; Londin, E.; et al. Posttranscriptional Regulation of PARG MRNA by HuR Facilitates DNA Repair and Resistance to PARP Inhibitors. Cancer Res. 2017, 77, 5011-5025. [CrossRef] [PubMed]

57. Masuda, K.; Abdelmohsen, K.; Kim, M.M.; Srikantan, S.; Lee, E.K.; Tominaga, K.; Selimyan, R.; Martindale, J.L.; Yang, X.; Lehrmann, E.; et al. Global Dissociation of HuR-MRNA Complexes Promotes Cell Survival after Ionizing Radiation. EMBO J. 2011, 30, 1040-1053. [CrossRef]

58. Mazan-Mamczarz, K.; Hagner, P.R.; Zhang, Y.; Dai, B.; Lehrmann, E.; Becker, K.G.; Keene, J.D.; Gorospe, M.; Liu, Z.; Gartenhaus, R.B. ATM Regulates a DNA Damage Response Posttranscriptional RNA Operon in Lymphocytes. Blood 2011, 117, 2441. [CrossRef]

59. Abdelmohsen, K.; Kuwano, Y.; Kim, H.H.; Gorospe, M. Posttranscriptional Gene Regulation by RNA-Binding Proteins during Oxidative Stress: Implications for Cellular Senescence. Biol. Chem. 2008, 389, 243-255. [CrossRef] [PubMed]

60. Saunus, J.M.; French, J.D.; Edwards, S.L.; Beveridge, D.J.; Hatchell, E.C.; Wagner, S.A.; Stein, S.R.; Davidson, A.; Simpson, K.J.; Francis, G.D.; et al. Posttranscriptional Regulation of the Breast Cancer Susceptibility Gene BRCA1 by the RNA Binding Protein HuR. Cancer Res. 2008, 68, 9469-9478. [CrossRef]

61. Mazan-Mamczarz, K.; Galbán, S.; De Silanes, I.L.; Martindale, J.L.; Atasoy, U.; Keene, J.D.; Gorospe, M. RNA-Binding Protein HuR Enhances P53 Translation in Response to Ultraviolet Light Irradiation. Proc. Natl. Acad. Sci. USA 2003, 100, 8354-8359. [CrossRef] [PubMed]

62. Wang, W.; Furneaux, H.; Cheng, H.; Caldwell, M.C.; Hutter, D.; Liu, Y.; Holbrook, N.; Gorospe, M. HuR Regulates P21 MRNA Stabilization by UV Light. Mol. Cell. Biol. 2000, 20, 760-769. [CrossRef]

63. Wang, W.; Caldwell, M.C.; Lin, S.; Furneaux, H.; Gorospe, M. HuR Regulates Cyclin A and Cyclin B1 MRNA Stability during Cell Proliferation. EMBO J. 2000, 19, 2340-2350. [CrossRef]

64. Heinonen, M.; Bono, P.; Narko, K.; Chang, S.H.; Lundin, J.; Joensuu, H.; Furneaux, H.; Hla, T.; Haglund, C.; Ristimäki, A Cytoplasmic HuR Expression Is a Prognostic Factor in Invasive Ductal Breast Carcinoma. Cancer Res. 2005, 65, 2157-2161. [CrossRef]

65. Xu, F.; Zhang, X.; Lei, Y.; Liu, X.; Liu, Z.; Tong, T.; Wang, W. Loss of Repression of HuR Translation by MiR-16 May Be Responsible for the Elevation of HuR in Human Breast Carcinoma. J. Cell. Biochem. 2010, 111, 727-734. [CrossRef] [PubMed]

66. Wang, J.; Li, D.; Wang, B.; Wu, Y. Predictive and Prognostic Significance of Cytoplasmic Expression of ELAV-like Protein HuR in Invasive Breast Cancer Treated with Neoadjuvant Chemotherapy. Breast Cancer Res. Treat. 2013, 141, 213-224. [CrossRef]

67. Palomo-Irigoyen, M.; Pérez-Andrés, E.; Iruarrizaga-Lejarreta, M.; Barreira-Manrique, A.; Tamayo-Caro, M.; Vila-Vecilla, L.; Moreno-Cugnon, L.; Beitia, N.; Medrano, D.; Fernández-Ramos, D.; et al. HuR/ELAVL1 Drives Malignant Peripheral Nerve Sheath Tumor Growth and Metastasis. J. Clin. Investig. 2020, 130, 3848. [CrossRef] [PubMed]

68. Trabucchi, M.; Briata, P.; Garcia-Mayoral, M.; Haase, A.D.; Filipowicz, W.; Ramos, A.; Gherzi, R.; Rosenfeld, M.G. The RNABinding Protein KSRP Promotes the Biogenesis of a Subset of MicroRNAs. Nature 2009, 459, 1010-1014. [CrossRef] [PubMed] 
69. Zhang, X.; Wan, G.; Berger, F.G.; He, X.; Lu, X. The ATM Kinase Induces MicroRNA Biogenesis in the DNA Damage Response. Mol. Cell 2011, 41, 371-383. [CrossRef] [PubMed]

70. Liu, W.; Chou, C.F.; Liu, S.; Crossman, D.; Yusuf, N.; Wu, Y.; Chen, C.Y. KSRP Modulates Melanoma Growth and Efficacy of Vemurafenib. Biochim. Biophys. Acta-Gene Regul. Mech. 2019, 1862, 759-770. [CrossRef] [PubMed]

71. Bikkavilli, R.; Zerayesus, S.; Van Scoyk, M.; Wilson, L.; Wu, P.; Baskaran, A.; Tang, K.; Raheem, S.; Samuelson, B.; Reddy, N.; et al. K-Homology Splicing Regulatory Protein (KSRP) Promotes Post-Transcriptional Destabilization of Spry4 Transcripts in Non-Small Cell Lung Cancer. J. Biol. Chem. 2017, 292, 7423-7434. [CrossRef]

72. Yan, M.; Sun, L.; Li, J.; Yu, H.; Lin, H.; Yu, T.; Zhao, F.; Zhu, M.; Liu, L.; Geng, Q.; et al. RNA-Binding Protein KHSRP Promotes Tumor Growth and Metastasis in Non-Small Cell Lung Cancer. J. Exp. Clin. Cancer Res. 2019, 38, 1-17. [CrossRef] [PubMed]

73. Caiazza, F.; Oficjalska, K.; Tosetto, M.; Phelan, J.J.; Noonan, S.; Martin, P.; Killick, K.; Breen, L.; O’Neill, F.; Nolan, B.; et al. KH-Type Splicing Regulatory Protein Controls Colorectal Cancer Cell Growth and Modulates the Tumor Microenvironment. Am. J. Pathol. 2019, 189, 1916-1932. [CrossRef]

74. $\quad$ Lafarga, V.; Sung, H.; Haneke, K.; Roessig, L.; Pauleau, A.; Bruer, M.; Rodriguez-Acebes, S.; Lopez-Contreras, A.J.; Gruss, O.J.; Erhardt, S.; et al. TIAR Marks Nuclear G2/M Transition Granules and Restricts CDK 1 Activity under Replication Stress. EMBO Rep. 2019, 20, e46224. [CrossRef] [PubMed]

75. Sánchez-Jiménez, C.; Ludeña, M.D.; Izquierdo, J.M. T-Cell Intracellular Antigens Function as Tumor Suppressor Genes. Cell Death Dis. 2015, 6, e1669. [CrossRef]

76. Lee, T.-H.; Choi, J.Y.; Park, J.-M.; Kang, T.-H. Posttranscriptional Control of the Replication Stress Response via TTP-Mediated Claspin MRNA Stabilization. Oncogene 2020, 39, 3245-3257. [CrossRef] [PubMed]

77. Brennan, S.E.; Kuwano, Y.; Alkharouf, N.; Blackshear, P.J.; Gorospe, M.; Wilson, G.M. The MRNA-Destabilizing Protein Tristetraprolin Is Suppressed in Many Cancers, Altering Tumorigenic Phenotypes and Patient Prognosis. Cancer Res. 2009, 69, 5168-5176. [CrossRef] [PubMed]

78. Coelho, M.A.; de Carné Trécesson, S.; Rana, S.; Zecchin, D.; Moore, C.; Molina-Arcas, M.; East, P.; Spencer-Dene, B.; Nye, E.; Barnouin, K.; et al. Oncogenic RAS Signaling Promotes Tumor Immunoresistance by Stabilizing PD-L1 MRNA. Immunity 2017, 47, 1083-1099.e6. [CrossRef]

79. Fallahi, M.; Amelio, A.L.; Cleveland, J.L.; Rounbehler, R.J. CREB Targets Define the Gene Expression Signature of Malignancies Having Reduced Levels of the Tumor Suppressor Tristetraprolin. PLoS ONE 2014, 9, e115517. [CrossRef]

80. Kröhler, T.; Kessler, S.M.; Hosseini, K.; List, M.; Barghash, A.; Patial, S.; Laggai, S.; Gemperlein, K.; Haybaeck, J.; Müller, R.; et al. The MRNA-Binding Protein TTP/ZFP36 in Hepatocarcinogenesis and Hepatocellular Carcinoma. Cancers 2019, 11, 1754. [CrossRef]

81. Vogel, K.U.; Bell, L.S.; Galloway, A.; Ahlfors, H.; Turner, M. The RNA-Binding Proteins Zfp3611 and Zfp3612 Enforce the Thymic $\beta$-Selection Checkpoint by Limiting DNA Damage Response Signaling and Cell Cycle Progression. J. Immunol. 2016, 197, 2673. [CrossRef]

82. Hodson, D.; Janas, M.; Galloway, M.; Bell, S.E.; Andrews, S.; Li, C.M.; Pannell, R.; Siebel, C.W.; MacDonald, H.R.; Keersmaecker, K.D.; et al. Deletion of the RNA-Binding Proteins ZFP36L1 and ZFP36L2 Leads to Perturbed Thymic Development and T Lymphoblastic Leukemia. Nat. Immunol. 2010, 11, 717-724. [CrossRef] [PubMed]

83. Nik-Zainal, S.; Davies, H.; Staaf, J.; Ramakrishna, M.; Glodzik, D.; Zou, X.; Martincorena, I.; Alexandrov, L.B.; Martin, S.; Wedge, D.C.; et al. Landscape of Somatic Mutations in 560 Breast Cancer Whole Genome Sequences. Nature 2016, 534, 47. [CrossRef] [PubMed]

84. Maura, F.; Bolli, N.; Angelopoulos, N.; Dawson, K.J.; Leongamornlert, D.; Martincorena, I.; Mitchell, T.J.; Fullam, A.; Gonzalez, S.; Szalat, R.; et al. Genomic Landscape and Chronological Reconstruction of Driver Events in Multiple Myeloma. Nat. Commun. 2019, 10, 1-12. [CrossRef] [PubMed]

85. Kaehler, M.; Dworschak, M.; Rodin, J.P.; Ruemenapp, J.; Vater, I.; Penas, E.; Liu, C.; Cascorbi, I.; Nage, I. ZFP36L1 Plays an Ambiguous Role in the Regulation of Cell Expansion and Negatively Regulates CDKN1A in Chronic Myeloid Leukemia Cells. Exp. Hematol. 2021, 99, 54-64.e7. [CrossRef]

86. Noguchi, A.; Adachi, S.; Yokota, N.; Hatta, T.; Natsume, T.; Kawahara, H. ZFP36L2 Is a Cell Cycle-Regulated CCCH Protein Necessary for DNA Lesion-Induced S-Phase Arrest. Biol. Open 2018, 7, bio031575. [CrossRef] [PubMed]

87. Xing, R.; Zhou, Y.; Yu, J.; Yu, Y.; Nie, Y.; Luo, W.; Yang, C.; Xiong, T.; Wu, W.K.K.; Li, Z.; et al. Whole-Genome Sequencing Reveals Novel Tandem-Duplication Hotspots and a Prognostic Mutational Signature in Gastric Cancer. Nat. Commun. 2019, 10, 1-13. [CrossRef] [PubMed]

88. Yonemori, K.; Seki, N.; Kurahara, H.; Osako, Y.; Idichi, T.; Arai, T.; Koshizuka, K.; Kita, Y.; Maemura, K.; Natsugoe, S. ZFP36L2 Promotes Cancer Cell Aggressiveness and Is Regulated by Antitumor MicroRNA-375 in Pancreatic Ductal Adenocarcinoma. Cancer Sci. 2017, 108, 124-135. [CrossRef]

89. Priestley, P.; Baber, J.; Lolkema, M.P.; Steeghs, N.; de Bruijn, E.; Shale, C.; Duyvesteyn, K.; Haidari, S.; van Hoeck, A.; Onstenk, W.; et al. Pan-Cancer Whole-Genome Analyses of Metastatic Solid Tumours. Nature 2019, 575, 210-216. [CrossRef]

90. Caldon, C.E.; Musgrove, E.A. Distinct and Redundant Functions of Cyclin E1 and Cyclin E2 in Development and Cancer. Cell Div. 2010, 5, 2. [CrossRef] [PubMed]

91. Kim, H.H.; Abdelmohsen, K.; Gorospe, M. Regulation of HuR by DNA Damage Response Kinases. J. Nucleic Acids 2010, 2010, 981487. [CrossRef] [PubMed] 
92. Watanabe, R.; Ui, A.; Kanno, S.; Ogiwara, H.; Nagase, T.; Kohno, T.; Yasui, A. SWI/SNF Factors Required for Cellular Resistance to DNA Damage Include ARID1A and ARID1B and Show Interdependent Protein Stability. Cancer Res. 2014, 74, 2465-2475. [CrossRef] [PubMed]

93. Díaz-Muñoz, M.D.; Kiselev, V.Y.; Novère, N.L.; Curk, T.; Ule, J.; Turner, M. Tia1 Dependent Regulation of MRNA Subcellular Location and Translation Controls P53 Expression in B Cells. Nat. Commun. 2017, 8, 1-16. [CrossRef] [PubMed]

94. Sánchez-Jiménez, C.; Izquierdo, J.M. T-Cell Intracellular Antigens in Health and Disease. Cell Cycle 2015, 14, 2033-2043. [CrossRef]

95. Lal, A.; Abdelmohsen, K.; Pullmann, R.; Kawai, T.; Galban, S.; Yang, X.; Brewer, G.; Gorospe, M. Posttranscriptional Derepression of GADD $45 \alpha$ by Genotoxic Stress. Mol. Cell 2006, 22, 117-128. [CrossRef] [PubMed]

96. Galloway, A.; Turner, M. Cell Cycle RNA Regulons Coordinating Early Lymphocyte Development. Wiley Interdiscip. Rev. RNA 2017, 8, 1419. [CrossRef]

97. Solaiman, N.S.; Sidali, A.; Kishore, K.; Norton, J.D.; Radhakrishnan, K.; Surendranath, K.; Murphy, J.J. RNA-Binding Protein ZFP36L1 Supresses Replication Stress-Induced DNA Damage. (manuscript in preparation; to be submitted).

98. Suk, F.M.; Chang, C.C.; Lin, R.J.; Lin, S.Y.; Liu, S.C.; Jau, C.F.; Liang, Y.C. ZFP36L1 and ZFP36L2 Inhibit Cell Proliferation in a Cyclin D-Dependent and P53-Independent Manner. Sci. Rep. 2018, 8, 1-13. [CrossRef]

99. Lebedeva, S.; Jens, M.; Theil, K.; Schwanhäusser, B.; Selbach, M.; Landthaler, M.; Rajewsky, N. Transcriptome-Wide Analysis of Regulatory Interactions of the RNA-Binding Protein HuR. Mol. Cell 2011, 43, 340-352. [CrossRef]

100. Sedlyarov, V.; Fallman, J.; Ebner, F.; Huemer, J.; Sneezum, L.; Ivin, M.; Kreiner, K.; Tanzer, A.; Vogl, C.; Hofacker, I.; et al Tristetraprolin Binding Site Atlas in the Macrophage Transcriptome Reveals a Switch for Inflammation Resolution. Mol. Syst. Biol. 2016, 12, 868. [CrossRef]

101. Mukherjee, N.; Corcoran, D.L.; Nusbaum, J.D.; Reid, D.W.; Georgiev, S.; Hafner, M.; Ascano, M., Jr.; Tuschl, T.; Ohler, U.; Keene, J.D. Integrative Regulatory Mapping Indicates That the RNA-Binding Protein HuR (ELAVL1) Couples Pre-MRNA Processing and MRNA Stability. Mol. Cell 2011, 43, 327. [CrossRef]

102. Mukherjee, N.; Jacobs, N.C.; Hafner, M.; Kennington, E.A.; Nusbaum, J.D.; Tuschl, T.; Blackshear, P.J.; Ohler, U. Global Target MRNA Specification and Regulation by the RNA-Binding Protein ZFP36. Genome Biol. 2014, 15, 1-16. [CrossRef]

103. Bakheet, T.; Hitti, E.; Al-Saif, M.; Moghrabi, W.N.; Khabar, K.S.A. The AU-Rich Element Landscape across Human Transcriptome Reveals a Large Proportion in Introns and Regulation by ELAVL1/HuR. Biochim. Biophys. Acta-Gene Regul. Mech. 2018, 1861, 167-177. [CrossRef] [PubMed]

104. Jungmichel, S.; Rosenthal, F.; Altmeyer, M.; Lukas, J.; Hottiger, M.O.; Nielsen, M.L. Proteome-Wide Identification of Poly(ADPRibosyl)Ation Targets in Different Genotoxic Stress Responses. Mol. Cell 2013, 52, 272-285. [CrossRef]

105. Abdelmohsen, K.; Pullmann, R.; Lal, A.; Kim, H.H.; Galban, S.; Yang, X.; Blethrow, J.D.; Walker, M.; Shubert, J.; Gillespie, D.A.; et al. Phosphorylation of HuR by Chk2 Regulates SIRT1 Expression. Mol. Cell 2007, 25, 543-557. [CrossRef] [PubMed]

106. Reinhardt, H.C.; Hasskamp, P.; Schmedding, I.; Morandell, S.; van Vugt, M.A.T.M.; Wang, X.Z.; Linding, R.; Ong, S.E.; Weaver, D.; Carr, S.A.; et al. DNA Damage Activates a Spatially Distinct Late Cytoplasmic Cell-Cycle Checkpoint Network Controlled by MK2-Mediated RNA Stabilization. Mol. Cell 2010, 40, 34-49. [CrossRef] [PubMed]

107. Han, C.; Wan, G.; Langley, R.R.; Zhang, X.; Lu, X. Crosstalk between the DNA Damage Response Pathway and MicroRNAs. Cell. Mol. Life Sci. 2012, 69, 2895-2906. [CrossRef]

108. Moskwa, P.; Buffa, F.M.; Pan, Y.; Panchakshari, R.; Gottipati, P.; Muschel, R.J.; Beech, J.; Kulshrestha, R.; Abdelmohsen, K.; Weinstock, D.M.; et al. MiR-182-Mediated Downregulation of BRCA1 Impacts DNA Repair and Sensitivity to PARP Inhibitors. Mol. Cell 2011, 41, 210-220. [CrossRef] [PubMed]

109. Murata, T.; Yoshino, Y.; Morita, N.; Kaneda, N. Identification of Nuclear Import and Export Signals within the Structure of the Zinc Finger Protein TIS11. Biochem. Biophys. Res. Commun. 2002, 293, 1242-1247. [CrossRef]

110. Anderson, P.; Kedersha, N. RNA Granules: Post-Transcriptional and Epigenetic Modulators of Gene Expression. Nat. Rev. Mol. Cell Biol. 2009, 10, 430-436. [CrossRef]

111. Phillips, R.S.; Ramos, S.B.V.; Blackshear, P.J. Members of the Tristetraprolin Family of Tandem CCCH Zinc Finger Proteins Exhibit CRM1-Dependent Nucleocytoplasmic Shuttling. J. Biol. Chem. 2002, 277, 11606-11613. [CrossRef]

112. Liang, J.; Lei, T.; Song, Y.; Yanes, N.; Qi, Y.; Fu, M. RNA-Destabilizing Factor Tristetraprolin Negatively Regulates NF- $k B$ Signaling. J. Biol. Chem. 2009, 284, 29383. [CrossRef]

113. Twizere, J.-C.; Kruys, V.; Lefeèbvre, L.; Vanderplasschen, A.; Collete, D.; Debacq, C.; Lai, W.S.; Jauniaux, J.-C.; Bernstein, L.R.; Semmes, O.J.; et al. Interaction of Retroviral Tax Oncoproteins With Tristetraprolin and Regulation of Tumor Necrosis Factor- $\alpha$ Expression. JNCI J. Natl. Cancer Inst. 2003, 95, 1846-1859. [CrossRef] [PubMed]

114. Matsuura, Y.; Noguchi, A.; Sakai, S.; Yokota, N.; Kawahara, H. Nuclear Accumulation of ZFP36L1 Is Cell Cycle-Dependent and Determined by a C-Terminal Serine-Rich Cluster. J. Biochem. 2020, 168, 477-489. [CrossRef]

115. Kim, H.H.; Gorospe, M. Phosphorylated HuR Shuttles in Cycles. Cell Cycle 2008, 7, 3124. [CrossRef] [PubMed]

116. Al-Khalaf, H.H.; Aboussekhra, A. ATR Controls the UV-Related Upregulation of the CDKN1A MRNA in a Cdk1/HuR-Dependent Manner. Mol. Carcinog. 2014, 53, 979-987. [CrossRef]

117. Barkauskaite, E.; Brassington, A.; Tan, E.S.; Warwicker, J.; Dunstan, M.S.; Banos, B.; Lafite, P.; Ahel, M.; Mitchison, T.J.; Ahel, I.; et al. Visualization of Poly(ADP-Ribose) Bound to PARG Reveals Inherent Balance between Exo- and Endo-Glycohydrolase Activities. Nat. Commun. 2013, 4, 1-8. [CrossRef] [PubMed] 
118. Fisher, A.E.; Hochegger, H.; Takeda, S.; Caldecott, K.W. Poly(ADP-Ribose) Polymerase 1 Accelerates Single-Strand Break Repair in Concert with Poly(ADP-Ribose) Glycohydrolase. Mol. Cell. Biol. 2007, 27, 5597-5605. [CrossRef] [PubMed]

119. Förch, P.; Puig, O.; Kedersha, N.; Martínez, C.; Granneman, S.; Séraphin, B.; Anderson, P.; Valcárcel, J. The Apoptosis-Promoting Factor TIA-1 Is a Regulator of Alternative Pre-MRNA Splicing. Mol. Cell 2000, 6, 1089-1098. [CrossRef]

120. Taupin, J.; Tian, Q.; Kedersha, N.; Robertson, M.; Anderson, P. The RNA-Binding Protein TIAR Is Translocated from the Nucleus to the Cytoplasm during Fas-Mediated Apoptotic Cell Death. Proc. Natl. Acad. Sci. USA 1995, 92, 1629-1633. [CrossRef]

121. Suswam, E.A.; Li, Y.Y.; Mahtani, H.; King, P.H. Novel DNA-Binding Properties of the RNA-Binding Protein TIAR. Nucleic Acids Res. 2005, 33, 4507-4518. [CrossRef] [PubMed]

122. Huertas, P. DNA Resection in Eukaryotes: Deciding How to Fix the Break. Nat. Struct. Mol. Biol. 2010, 17, 11-16. [CrossRef] [PubMed]

123. Iacovoni, J.S.; Caron, P.; Lassadi, I.; Nicolas, E.; Massip, L.; Trouche, D.; Legube, G. High-Resolution Profiling of GammaH2AX around DNA Double Strand Breaks in the Mammalian Genome. EMBO J. 2010, 29, 1446-1457. [CrossRef]

124. Spagnolo, L.; Rivera-Calzada, A.; Pearl, L.H.; Llorca, O. Three-Dimensional Structure of the Human DNA-PKcs/Ku70/Ku80 Complex Assembled on DNA and Its Implications for DNA DSB Repair. Mol. Cell 2006, 22, 511-519. [CrossRef] [PubMed]

125. Kumar, M.; Matta, A.; Masui, O.; Srivastava, G.; Kaur, J.; Thakar, A.; Shukla, N.K.; RoyChoudhury, A.; Sharma, M.; Walfish, P.G.; et al. Nuclear Heterogeneous Nuclear Ribonucleoprotein D Is Associated with Poor Prognosis and Interactome Analysis Reveals Its Novel Binding Partners in Oral Cancer. J. Transl. Med. 2015, 13, 285. [CrossRef] [PubMed]

126. Roberts, R.W.; Crothers, D.M. Stability and Properties of Double and Triple Helices: Dramatic Effects of RNA or DNA Backbone Composition. Science 1992, 258, 1463-1466. [CrossRef] [PubMed]

127. Westover, K.D.; Bushnell, D.A.; Kornberg, R.D. Structural Basis of Transcription: Nucleotide Selection by Rotation in the RNA Polymerase II Active Center. Cell 2004, 119, 481-489. [CrossRef] [PubMed]

128. Santos-Pereira, J.M.; Aguilera, A. R Loops: New Modulators of Genome Dynamics and Function. Nat. Rev. Genet. 2015, 16, 583-597. [CrossRef]

129. Gan, W.; Guan, Z.; Liu, J.; Gui, T.; Shen, K.; Manley, J.L.; Li, X. R-Loop-Mediated Genomic Instability Is Caused by Impairment of Replication Fork Progression. Genes Dev. 2011, 25, 2041-2056. [CrossRef]

130. Gómez-González, B.; Aguilera, A. Activation-Induced Cytidine Deaminase Action Is Strongly Stimulated by Mutations of the THO Complex. Proc. Natl. Acad. Sci. USA 2007, 104, 8409-8414. [CrossRef]

131. Hamperl, S.; Bocek, M.J.; Saldivar, J.C.; Swigut, T.; Cimprich, K.A. Transcription-Replication Conflict Orientation Modulates R-Loop Levels and Activates Distinct DNA Damage Responses. Cell 2017, 170, 774-786.e19. [CrossRef]

132. Stirling, P.C.; Hieter, P. Canonical DNA Repair Pathways Influence R-Loop-Driven Genome Instability. J. Mol. Biol. 2017, 429, 3132-3138. [CrossRef]

133. Stirling, P.C.; Chan, Y.A.; Minaker, S.W.; Aristizabal, M.J.; Barrett, I.; Sipahimalani, P.; Kobor, M.S.; Hieter, P. R-Loop-Mediated Genome Instability in MRNA Cleavage and Polyadenylation Mutants. Genes Dev. 2012, 26, 163-175. [CrossRef] [PubMed]

134. Wahba, L.; Amon, J.D.; Koshland, D.; Vuica-Ross, M. RNase H and Multiple RNA Biogenesis Factors Cooperate to Prevent RNA:DNA Hybrids from Generating Genome Instability. Mol. Cell 2011, 44, 978-988. [CrossRef] [PubMed]

135. Huertas, P.; Aguilera, A. Cotranscriptionally Formed DNA: RNA Hybrids Mediate Transcription Elongation Impairment and Transcription-Associated Recombination. Mol. Cell 2003, 12, 711-721. [CrossRef] [PubMed]

136. Li, X.; Manley, J.L. Inactivation of the SR Protein Splicing Factor ASF/SF2 Results in Genomic Instability. Cell 2005, 122, 365-378. [CrossRef]

137. Tsantoulis, P.K.; Kotsinas, A.; Sfikakis, P.P.; Evangelou, K.; Sideridou, M.; Levy, B.; Mo, L.; Kittas, C.; Wu, X.-R.; Papavassiliou, A.G.; et al. Oncogene-Induced Replication Stress Preferentially Targets Common Fragile Sites in Preneoplastic Lesions. A Genome-Wide Study. Oncogene 2007, 27, 3256-3264. [CrossRef]

138. Arlt, M.F.; Durkin, S.G.; Ragland, R.L.; Glover, T.W. Common Fragile Sites as Targets for Chromosome Rearrangements. DNA Repair 2006, 5, 1126-1135. [CrossRef] [PubMed]

139. Bignell, G.R.; Greenman, C.D.; Davies, H.; Butler, A.P.; Edkins, S.; Andrews, J.M.; Buck, G.; Chen, L.; Beare, D.; Latimer, C.; et al. Signatures of Mutation and Selection in the Cancer Genome. Nature 2010, 463, 893-898. [CrossRef]

140. Hellman, A.; Zlotorynski, E.; Scherer, S.W.; Cheung, J.; Vincent, J.B.; Smith, D.I.; Trakhtenbrot, L.; Kerem, B. A Role for Common Fragile Site Induction in Amplification of Human Oncogenes. Cancer Cell 2002, 1, 89-97. [CrossRef]

141. Zlotorynski, E.; Rahat, A.; Skaug, J.; Ben-Porat, N.; Ozeri, E.; Hershberg, R.; Levi, A.; Scherer, S.W.; Margalit, H.; Kerem, B. Molecular Basis for Expression of Common and Rare Fragile Sites. Mol. Cell. Biol. 2003, 23, 7143. [CrossRef]

142. Helmrich, A.; Ballarino, B.; Tora, L. Collisions between Replication and Transcription Complexes Cause Common Fragile Site Instability at the Longest Human Genes. Mol. Cell 2011, 44, 966-977. [CrossRef] [PubMed]

143. Kumar, R.; Nagpal, G.; Kumar, V.; Usmani, S.S.; Agrawal, P.; Raghava, G.P.S. HumCFS: A Database of Fragile Sites in Human Chromosomes. BMC Genom. 2019, 19, 985. [CrossRef]

144. Pospisilova, H.; Baens, M.; Michaux, L.; Stul, M.; Van Hummelen, P.; Van Loo, P.; Vermeesch, J.; Jarosova, M.; Zemanova, Z.; Michalova, K.; et al. Interstitial Del(14)(q) Involving IGH: A Novel Recurrent Aberration in B-NHL. Leukemia 2007, 21, 2079-2083. [CrossRef] [PubMed]

145. Gonzalez-Perez, A.; Perez-Llamas, C.; Deu-Pons, J.; Tamborero, D.; Schroeder, M.P.; Jene-Sanz, A.; Santos, A.; Lopez-Bigas, N. IntOGen-Mutations Identifies Cancer Drivers across Tumor Types. Nat. Methods 2013, 10, 1081. [CrossRef] [PubMed] 
146. Rounbehler, R.J.; Fallahi, M.; Yang, C.; Steeves, M.A.; Li, W.; Doherty, J.R.; Schaub, F.K.; Sanduja, S.; Dixon, D.A.; Blackshear, P.J.; et al. Tristetraprolin Impairs Myc-Induced Lymphoma and Abolishes the Malignant State. Cell 2012, 150, 563-574. [CrossRef] [PubMed]

147. Planel, S.; Salomon, A.; Jalinot, P.; Feige, J.J.; Cherradi, N. A Novel Concept in Antiangiogenic and Antitumoral Therapy: Multitarget Destabilization of Short-Lived MRNAs by the Zinc Finger Protein ZFP36L1. Oncogene 2010, 29, 5989-6003. [CrossRef] [PubMed]

148. Shimada, H.; Ichikawa, H.; Ohki, M. Potential Involvement of the AML1-MTG8 Fusion Protein in the Granulocytic Maturation Characteristic of the $\mathrm{t}(8 ; 21)$ Acute Myelogenous Leukemia Revealed by Microarray Analysis. Leukemia 2002, 16, $874-885$. [CrossRef] 